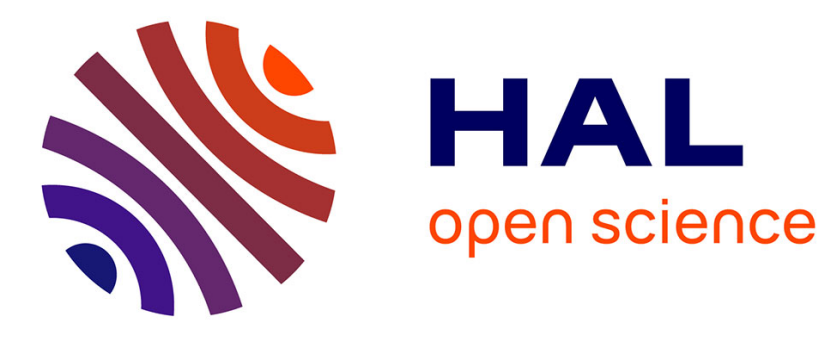

\title{
Silver behaviour along the salinity gradient of the Gironde Estuary
}

Laurent Lanceleur, Jörg Schäfer, Gérard Blanc, Alexandra Coynel, Cécile

Bossy, Magalie Baudrimont, Corine Glé, Aurélie Larrose, Emilie Strady, Sophie Renault

\section{To cite this version:}

Laurent Lanceleur, Jörg Schäfer, Gérard Blanc, Alexandra Coynel, Cécile Bossy, et al.. Silver behaviour along the salinity gradient of the Gironde Estuary. Environmental Science and Pollution Research, 2013, 20 (3), pp.1352-1366. 10.1007/s11356-012-1045-3 . hal-02357364

\section{HAL Id: hal-02357364 https://hal.science/hal-02357364}

Submitted on 13 Nov 2019

HAL is a multi-disciplinary open access archive for the deposit and dissemination of scientific research documents, whether they are published or not. The documents may come from teaching and research institutions in France or abroad, or from public or private research centers.
L'archive ouverte pluridisciplinaire HAL, est destinée au dépôt et à la diffusion de documents scientifiques de niveau recherche, publiés ou non, émanant des établissements d'enseignement et de recherche français ou étrangers, des laboratoires publics ou privés. 


\title{
Silver behaviour along the salinity gradient of the Gironde Estuary
}

\author{
Laurent Lanceleur \&Jörg Schäfer \&Gérard Blanc \& \\ Alexandra Coynel \&Cécile Bossy \&Magalie \\ Baudrimont \&Corine Glé \&Aurélie Larrose \&Sophie \\ Renault \&Emilie Strady
}

\begin{abstract}
Dissolved and particulate Ag concentrations $\left(A g_{D}\right.$ and $A g_{P}$, respectively) were measured in surface water and suspended particulate matter (SPM) along the salinity gradient of the Gironde Estuary, South West France, during three cruises (2008-2009) covering contrasting hydrological conditions, i.e. two cruises during intermediate and one during high freshwater discharge ( 740 and $\left.\sim 2,300 \mathrm{~m}^{3} / \mathrm{s}\right)$. Silver distribution reflected non-conservative behaviour with $60-70 \%$ of $\mathrm{Ag}_{\mathrm{P}}$ in freshwater particles being desorbed by chlorocomplexation. The amount of $\mathrm{Ag}_{\mathrm{P}}$ desorbed was similar to the so-called reactive, potentially bioavailable $\mathrm{Ag}_{\mathrm{P}}$ fraction $(60 \pm 4 \%)$ extracted from river SPM by $1 \mathrm{M}$ $\mathrm{HCl}$. Both $\operatorname{Ag}_{\mathrm{P}}(0.22 \pm 0.05 \mathrm{mg} / \mathrm{kg})$ and $\mathrm{Ag}_{\mathrm{P}} / \mathrm{Th}_{\mathrm{P}}(0.025-$ 0.028 ) in the residual fraction of fluvial and estuarine SPM were similar to those in SPM from the estuary mouth and in coastal sediments from the shelf off the Gironde Estuary, indicating that chlorocomplexation desorbs the reactive $\mathrm{Ag}_{\mathrm{P}}$. The data show that desorption of reactive $\mathrm{Ag}_{\mathrm{P}}$ mainly occurs inside the estuary during low and intermediate discharge, whereas expulsion of partially $\mathrm{Ag}_{\mathrm{P}}$-depleted SPM $\left(\mathrm{Ag}_{\mathrm{P}} / \mathrm{Th}_{\mathrm{P}}\right.$ 0.040) during the flood implies ongoing desorption in the coastal ocean, e.g. in the nearby oyster production areas (Marennes-Oléron Bay). The highest $\mathrm{Ag}_{\mathrm{D}}$ levels (6-8 ng/ L) occurred in the mid-salinity range (15-20) of the Gironde Estuary and were decoupled from freshwater discharge. In the maximum turbidity zone, $\mathrm{Ag}_{\mathrm{D}}$ were at minimum, showing that high SPM concentrations (a) induce $\mathrm{Ag}_{\mathrm{D}}$ adsorption in estuarine freshwater and (b) counterbalance $\mathrm{Ag}_{\mathrm{P}}$ desorption in the low salinity range (1-3). Accordingly, Ag behaviour in turbid estuaries appears to be controlled by the
\end{abstract}

L. Lanceleur (*) : J. Schäfer G. Blanc $^{\text {: A. Coynel }} \boldsymbol{C}_{\mathrm{C} . \text { Bossy }}$ :

M. Baudrimont $\bullet^{\text {C. Glé }} \bullet_{\text {A. Larrose }} \boldsymbol{S}_{\mathrm{S} \text {. Renault }} \bullet_{\text {E. Strady }}$

University of Bordeaux, EPOC, UMR 5805,

33405 Talence CEDEX, France

e-mail: 1.lanceleur@epoc.u-bordeaux1.fr balance between salinity and SPM levels. The first estimates of daily $\mathrm{Ag}_{\mathrm{D}}$ net fluxes for the Gironde Estuary (Boyle's method) showed relatively stable theoretical $\mathrm{Ag}_{\mathrm{D}}$ at zero salinity ( $\left.\operatorname{Ag}_{\mathrm{D}}^{0} 025-30 \mathrm{ng} / \mathrm{L}\right)$ for the contrasting hydrological situations. Accordingly, $\mathrm{Ag}_{\mathrm{D}}$ net fluxes were very similar for the situations with intermediate discharge (1.7 and $1.6 \mathrm{~g} /$ day) and clearly higher during the flood $(5.0 \mathrm{~g} /$ day $)$ despite incomplete desorption. Applying $\mathrm{Ag}_{\mathrm{D}}$ to the annual freshwater inputs provided an annual net $\mathrm{Ag}_{\mathrm{D}}$ flux (0.64$0.89 \mathrm{t} /$ year in 2008 and $0.56-0.77 \mathrm{t} /$ year in 2009) that was 12-50 times greater than the $\mathrm{Ag}_{\mathrm{D}}$ gross flux. This estimate was consistent with net $\mathrm{Ag}_{\mathrm{D}}$ flux estimates obtained from gross $\mathrm{Ag}_{\mathrm{P}}$ flux considering $60 \%$ desorption in the estuarine salinity gradient.

Keywords Chlorocomplexation · Silver addition · Marine geochemistry $\cdot$ Ion exchange $\cdot$ Isotope dilution

\section{Introduction}

The ionic form of $\mathrm{Ag}$ has been shown to be the most toxic Ag species (Eisler 1996; Ratte 1999), its occurrence in saltwater is almost nil and Ag chlorocomplex is the dominant dissolved $\mathrm{Ag}\left(\mathrm{Ag}_{\mathrm{D}}\right)$ form in saltwater (Barriada et al. 2007). However, estuarine bivalves and crustaceans accumulate Ag principally from water (e.g. Eisler 1996). The bioavailability of $\mathrm{Ag}$ chloride complex is mainly due to the ability of the neutral $\mathrm{AgCl}_{(\mathrm{aq})}$ specie to diffuse passively through cell membrane (Engel et al. 1981). Even if $\mathrm{AgCl}_{(\mathrm{aq})}$ is less toxic than the ionic form $\mathrm{Ag}^{+}, \mathrm{Ag}$ is one of the most toxic metal for the early life stages of invertebrates and algae in marine and estuarine environments (Bryan and Langston 1992). Sublethal effects of $\mathrm{Ag}$ on invertebrates such as diminishing their reproductive capability have been shown in estuarine saltwater (Hornberger et al. 2000) at relatively 
moderate levels of environmental contamination compared to guideline values recommended by the United States Environmental Protection Agency for Ag protection (1,920 and 3,200 $\mathrm{ng} / \mathrm{L}$ in saltwater and freshwater, respectively;

U.S. EPA 2002).

In former times, anthropogenic Ag inputs into aquatic systems were mainly due to acid mine drainage and metallurgy (e.g. Ayrault et al. 2010; Lanceleur et al. 2011a, $\underline{\text { b; }}$; Tappin et al. 2010). However, since the late nineteenth century, Ag use has diversified (e.g. photography, electronics; e.g. Flegal et al. 2007) and intensified, making Ag a classical tracer of urban wastewater inputs (Rozan and Hunter 2001; Sañudo-Wilhelmy and Flegal 1992; Tappin et al. 2010).

Although there is a general lack of data on dissolved Ag concentrations and fluxes in fluvial and estuarine systems at the global scale (Gobeil et al. 2005; Lanceleur et al. 2011a; Zhang et al. 2008), Ag behaviour and fate have been thoroughly studied in a few heavily polluted systems, such as the San Francisco Bay, named the 'Silver Estuary' (e.g. Flegal et al. 2007). This long-term case study has shown that the closure of a large photograph processing plant, growing Ag recycling and rehabilitation of the sewage treatment plant has decreased $\mathrm{Ag}$ levels in biota, sediment and water of the bay (e.g. Flegal et al. 2007; Hornberger et al. $\underline{2000)}$.

In freshwater systems, $\mathrm{Ag}_{\mathrm{D}}$ inputs are efficiently and rapidly (within some minutes) adsorbed onto suspended particles (Davis 1977; Smith and Flegal 1993), i.e. Ag transport and distribution closely depend on particle mobility. Consequently, sediments may stock Ag, indicating former pollution and act as both sinks and secondary sources when remobilisation occurs due to natural (floods, diagenetic recycling) or anthropogenic (dredging, dam management) processes (Audry et al. 2004; Ayrault et al. 2010; Coynel et al. 2007; Lanceleur et al. 2011b). In the Gironde watershed, $96 \%$ of the fluvial Ag transport occurs in the particulate phase (Lanceleur et al. 2011a). When particles reach the saline part of the estuary, dissolved chlorides induce partial particulate $\mathrm{Ag}\left(\mathrm{Ag}_{\mathrm{P}}\right)$ desorption by the formation of dissolved Ag chlorocomplex (Luoma et al. 1995). The dissolved form of Ag being the most bioavailable (Engel et al. 1981), such desorption increases exposure and in fine vulnerability of estuarine and costal organisms.

The potentially bioavailable particulate $\mathrm{Ag}$, estimated as the $\mathrm{HCl}$-extractable fraction $\left(\mathrm{Ag}_{\mathrm{HCl}}\right.$; e.g. Morse and Luther 1999) in estuarine sediment of the San Francisco Bay, was correlated with $\mathrm{Ag}$ concentrations in clams (Scrobicularia plana; Luoma et al. 1995). Furthermore, the presence of chlorides limits Ag adsorption onto solid phases, such as iron oxides (Davis 1977), probably increasing the persistence of $\mathrm{Ag}_{\mathrm{D}}$ in saline estuarine waters. Data on Ag levels and partitioning in estuarine salinity gradients exist for a few estuaries that are not considered turbid (e.g. Flegal et al. 2007; Tappin et al. 2010).

The Gironde Estuary (Fig. 1) is a highly turbid estuary affected by historical metal pollution $(\mathrm{Cd}, \mathrm{Pb}, \mathrm{Zn}, \mathrm{Cu}, \mathrm{Hg}$, As) mainly due to geology, former mining and ore treatment (Audry et al. 2004; Castelle et al. 2007) and by agricultural activities (Masson et al. 2006). In 2004-2005, the French Mussel Watch Programme (RNO) revealed anomalously high Ag concentrations in oysters (Crassostrea gigas) from the estuary mouth (Chiffoleau et al. 2005). Historical records of Ag levels in reservoir sediments and in oysters from the estuary mouth suggested that (a) the former ore treatment in the watershed was a major Ag source to the Gironde Estuary for at least 50 years and (b) increasing Ag levels in oysters since the 1990s are due to more contemporary sources, likely urban wastewater (e.g. from the Bordeaux agglomeration; Fig. 1; Lanceleur et al. 2011b).

The present work aims to study dissolved and particulate $\mathrm{Ag}$ levels and partitioning in the salinity and turbidity gradients of the Gironde Estuary under contrasting hydrological situations, providing the first information on $\mathrm{Ag}$ behaviour in turbid estuaries. Furthermore, we estimate daily $\mathrm{Ag}_{\mathrm{D}}$ net fluxes exported to the Atlantic coastal waters and discuss the potential transfer of dissolved and particulate $\mathrm{Ag}$ to the near oyster production zone in the Marennes-Oléron Bay.

\section{Materials and methods}

\section{Study area}

The Gironde Estuary ( 170 km length; Fig. 1) is the largest estuary of the European Atlantic Coast draining a watershed $\left(80,000 \mathrm{~km}^{2}\right)$ with only two big urban agglomerations (Bordeaux and Toulouse; 2.7 million inhabitants).

Systematic research on its physical, geochemical and hydrological characteristics over several decades has made the Gironde Estuary a model system for the understanding of meso- to macrotidal, turbid estuaries (e.g. Audry et al. 2006; Sottolichio and Castaing 1999). Its mean annual freshwater discharge is $\sim 1,000 \mathrm{~m}^{3} / \mathrm{s}$ over the last 90 years, but discharges tend to decrease continuously and a mean of $\sim 770 \mathrm{~m}^{3} / \mathrm{s}$ is more representative of freshwater discharge on the last 10 years (Port Autonome de Bordeaux; DIrection Régionale de l'ENvironement). Ocean water fluxes at the estuary mouth are 30-40 times higher than fluvial inputs, and the asymmetrical progression of the tidal wave toward the upstream estuary induces a pronounced maximum turbidity zone (MTZ), where concentrations of suspended particulate matter (SPM) exceed $1 \mathrm{~g} / \mathrm{L}$ in surface water and several hundreds of grams per litre in bottomwater (Sottolichio and Castaing 1999). The MTZ is typically 
Fig. 1 Map of the Gironde Estuary, South West France. Kilometric point (KP): distance (kilometre) from Bordeaux. The core in the West Gironde Mud Patch (WGMP; grey dashed area) is described in Schmidt et al. (2005)
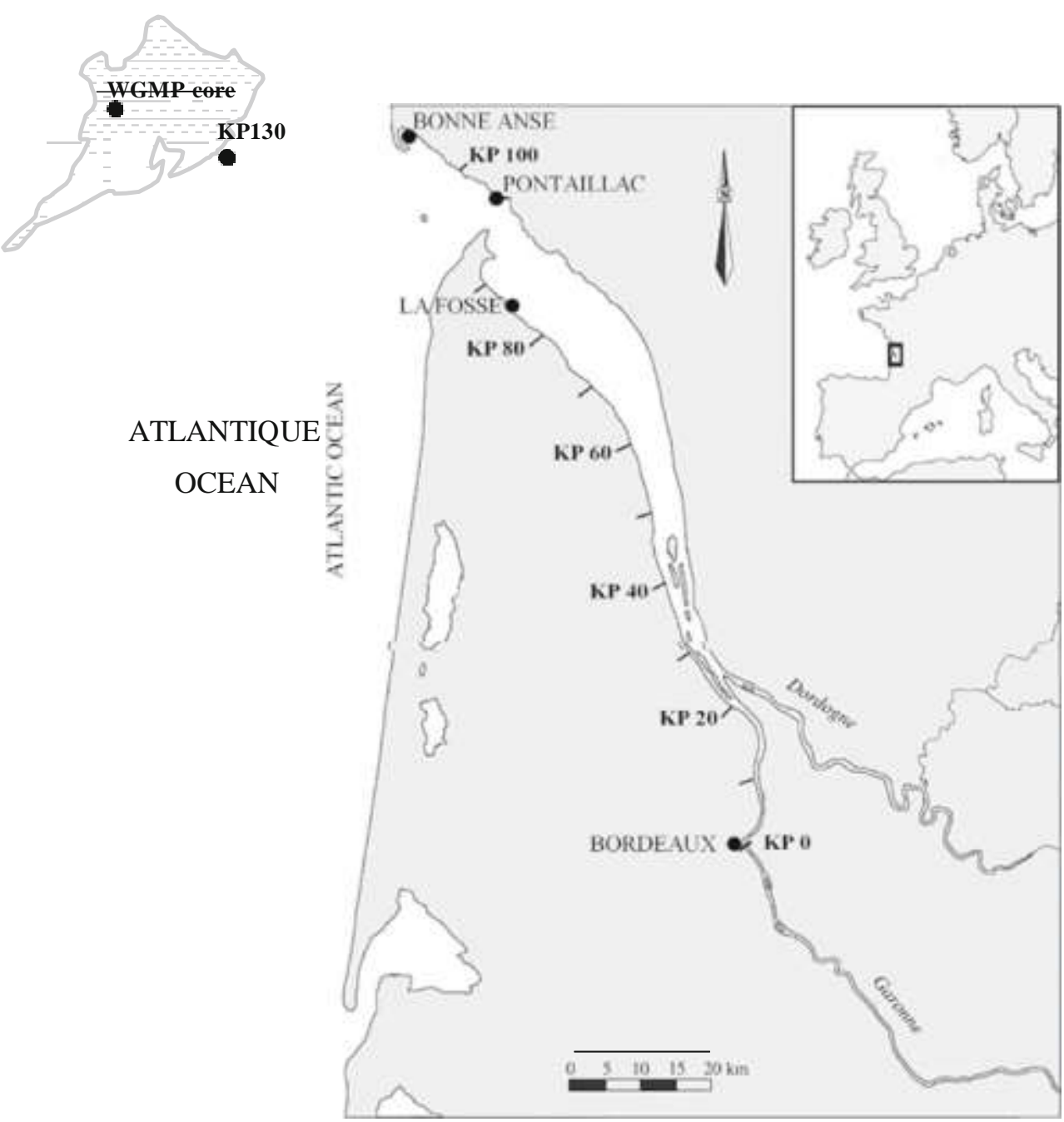

located in the low salinity $(S)$ region and migrates up and down estuary as a function of both tidal currents and seasonal river flow variations (Sottolichio and Castaing 1999). Typical water and particle residence times were estimated at $~ 20-90$ days and $~ 1-2$ years respectively, depending on the season (Jouanneau and Latouche 1981).

\section{Sampling}

Particle and water samples were continuously sampled for one and a half days during three cruises, in April 2008, March and June 2009, along longitudinal profiles in the salinity and turbidity gradients in surface water ( 1 $\mathrm{m}$ depth) of the Gironde Estuary covering contrasting hydrological situations (Table 1). All the labware in contact with the samples were acid-washed $\left(72 \mathrm{~h}\right.$ in $10 \% v / v \mathrm{HNO}_{3}, 14 \mathrm{M}$, J.T. Baker) and thoroughly rinsed with double deionised water (Milli-Q, Millipore). Sampling of surface waters (1 $\mathrm{m}$ depth) in the estuarine salinity gradient was performed with an acid-washed Niskin bottle, thoroughly rinsed with estuarine water from the site. Collected waters were immediately filtered through cellulose acetate syringe filters $(0.2 \mu \mathrm{m}$, Sartorius) and transferred into two $60 \mathrm{~mL}$ acidwashed polypropylene (PP) bottles. One of the replicates was immediately UV-irradiated by passing through a quartz coil (5 m long; internal diameter $2 \mathrm{~mm}$ ) around a UV lamp $(254 \mathrm{~nm}, 40 \mathrm{~W}$ ) at $0.5 \mathrm{~mL} / \mathrm{min}$ speed (i.e. $30 \mathrm{~min}$ irradiation time) in order to break down dissolved/colloidal Ag metalorganic complexes (e.g. Wu et al. 2004). Following acidification (ultrapure $\mathrm{HCl} ; 0.5 \% v / v$, J.T. Baker), the samples were double-bagged and sealed in polyethylene bags, then stored in the dark at $4{ }^{\circ} \mathrm{C}$ until analysis.

Suspended particles were collected by pumping 40$200 \mathrm{~L}$ of water (depending on the turbidity) through polyethylene tubing with a peristaltic pump $(50 \mathrm{~L} / \mathrm{min})$, collected in a container previously rinsed with water from the site and immediately centrifuged (Westfalia Separator; 12,000× $g$; $60 \mathrm{~L} / \mathrm{h}$ ) as described elsewhere (e.g. Masson et al. 2006; Schäfer and Blanc 2002). Particle samples were stored in the dark at $-20{ }^{\circ} \mathrm{C}$ in double plastic bags until arrival in the laboratory, then centrifuged at $4-6{ }^{\circ} \mathrm{C}$ to remove remaining saltwater (Jouan CR4.12; 4,000 $\times g$ ). Fifteen additional 
Table 1 Sampling station data for salinity $(S)$, locations (KP; i.e. distance from Bordeaux in kilometre), suspended particulate matter (SPM), dissolved and particulate organic matter (DOM and POM), chlorophyll- $a(\mathrm{Chl}-a)$, particulate $\mathrm{Ag}\left(\mathrm{Ag}_{\mathrm{P}}\right)$, particulate $\mathrm{Th}\left(\mathrm{Th}_{\mathrm{P}}\right)$, $\mathrm{Ag}_{\mathrm{P}} / \mathrm{Th}_{\mathrm{P}}$, dissolved $\mathrm{Ag}\left(\mathrm{Ag}_{\mathrm{D}}\right)$ and dissolved $\mathrm{Ag}$ after photo-oxidation $\left(\mathrm{UV}-\mathrm{Ag}_{\mathrm{D}}\right)$

\begin{tabular}{|c|c|c|c|c|c|c|c|c|c|c|c|}
\hline Station & $S$ & PK & $\begin{array}{l}\mathrm{SPM} \\
(\mathrm{mg} / \mathrm{L})\end{array}$ & $\begin{array}{l}\mathrm{DOC} \\
(\mathrm{mg} / \mathrm{L})\end{array}$ & $\begin{array}{l}\text { POC } \\
(\%)\end{array}$ & $\begin{array}{l}\text { Chl- } a \\
(\mu \mathrm{g} / \mathrm{L})\end{array}$ & $\begin{array}{l}\mathrm{Ag}_{\mathrm{P}} \\
(\mathrm{mg} / \mathrm{kg})\end{array}$ & $\begin{array}{l}\mathrm{Th}_{\mathrm{P}} \\
(\mathrm{mg} / \mathrm{kg})\end{array}$ & $\mathrm{Ag}_{\mathrm{P}} / \mathrm{Th}_{\mathrm{P}}$ & $\begin{array}{l}\mathrm{Ag}_{\mathrm{D}} \\
(\mathrm{ng} / \mathrm{L})\end{array}$ & $\begin{array}{l}\mathrm{UV}-\mathrm{Ag}_{\mathrm{D}} \\
(\mathrm{ng} / \mathrm{L})\end{array}$ \\
\hline \multicolumn{12}{|c|}{ April 2008; discharge $02,320 \mathrm{~m}^{3} / \mathrm{s}$} \\
\hline GMC 601 & 0 & 3 & 41 & 2.3 & & & 0.60 & 12.12 & 0.049 & 2.4 & 3.0 \\
\hline GMC 602 & 1.1 & 59 & 550 & 1.5 & 1.8 & & 0.56 & 9.43 & 0.060 & 1.3 & 2.5 \\
\hline GMC 603 & 2.5 & 71 & 2,660 & 3.1 & 1.4 & & 0.62 & 12.85 & 0.048 & 1.4 & 1.4 \\
\hline GMC 604 & 4.0 & 77 & 1,040 & 2.2 & 1.6 & & 0.61 & 10.16 & 0.060 & 2.2 & 2.3 \\
\hline GMC 605 & 7.0 & 81 & 668 & 1.4 & 1.7 & & 0.60 & 11.34 & 0.053 & 3.2 & 3.2 \\
\hline GMC 609 & 8.5 & 81 & 145 & 1.5 & 1.5 & & 0.54 & 8.41 & 0.064 & 4.0 & 4.2 \\
\hline GMC 608 & 10.8 & 86 & 166 & 1.9 & 1.4 & & 0.55 & 9.02 & 0.061 & 4.8 & 6.1 \\
\hline GMC 607 & 13.0 & 91 & 122 & 1.4 & 1.5 & & 0.55 & 10.96 & 0.050 & 5.5 & 6.4 \\
\hline GMC 606 & 14.7 & 95 & 177 & 1.5 & 1.5 & & 0.55 & 9.07 & 0.060 & 6.5 & 7.7 \\
\hline GMC 610 & 16.2 & 92 & 43 & 1.5 & 1.4 & & 0.49 & 11.51 & 0.042 & & \\
\hline GMC 611 & 20.2 & 95 & 47 & 1.2 & 1.5 & & 0.43 & 10.05 & 0.043 & 6.3 & 7.6 \\
\hline GMC 612 & 22.3 & 105 & 30 & 0.8 & 1.4 & & 0.32 & 8.35 & 0.038 & & \\
\hline GMC 613 & 27.1 & 110 & 72 & 1.6 & 1.4 & & 0.37 & 9.67 & 0.038 & 4.4 & 5.9 \\
\hline GMC 615 & 29.7 & 128 & 12 & 1.6 & 1.3 & & 0.21 & 5.45 & 0.039 & & \\
\hline GMC 614 & 29.8 & 112 & 32 & 1.8 & 1.2 & & 0.28 & 7.00 & 0.040 & & \\
\hline \multicolumn{12}{|c|}{ March 2009; discharge $0747 \mathrm{~m}^{3} / \mathrm{s}$} \\
\hline METOGIR2 st11 & 0 & 2 & 41 & & & & 0.48 & 11.70 & 0.041 & 1.2 & 1.3 \\
\hline METOGIR2 st10 & 0.1 & 22 & 256 & & & 0.4 & 0.34 & 11.97 & 0.029 & 0.8 & 0.9 \\
\hline METOGIR2 st9 & 0.7 & 30 & 250 & & & 0.2 & 0.32 & 10.74 & 0.030 & 0.7 & 0.7 \\
\hline METOGIR2 st8 & 3.4 & 44 & 198 & & & 0.5 & 0.36 & 9.00 & 0.040 & 0.9 & 1.0 \\
\hline METOGIR2 st7 & 6.1 & 55 & 102 & & & 1.1 & 0.38 & 12.34 & 0.031 & 1.5 & 1.9 \\
\hline METOGIR2 st6 & 8.4 & 57 & 63 & & & 1.1 & 0.35 & 11.00 & 0.032 & 2.1 & 2.7 \\
\hline METOGIR2 st2 & 11.0 & 87 & 34 & & & 0.5 & 0.33 & 12.19 & 0.027 & 1.2 & 2.3 \\
\hline METOGIR2 st5 & 11.2 & 80 & 38 & & & 0.6 & 0.32 & 10.62 & 0.030 & 2.2 & 2.3 \\
\hline METOGIR2 st3 & 13.7 & 89 & 30 & & & 0.6 & 0.30 & 12.45 & 0.024 & 2.5 & 2.6 \\
\hline METOGIR2 st4 & 15.6 & 92 & 27 & & & 0.5 & 0.28 & 10.10 & 0.028 & 3.2 & 3.2 \\
\hline METOGIR2 st1 & 17.3 & 87 & 32 & & & 0.7 & 0.32 & 11.19 & 0.029 & 4.6 & 4.8 \\
\hline VTR5 Coubre st10 & 18.2 & 95 & 71 & & 1.4 & 0.8 & 0.31 & 11.38 & 0.027 & 4.6 & 5.0 \\
\hline VTR5 Coubre St9 & 19.8 & 103 & 52 & & 1.5 & 0.8 & 0.29 & 12.53 & 0.023 & 5.8 & 6.3 \\
\hline VTR5 Coubre St8 & 23.0 & 108 & 45 & & 1.6 & 0.9 & 0.31 & 12.84 & 0.024 & 3.3 & 5.2 \\
\hline VTR5 Coubre St7 & 25.4 & 112 & 31 & & 1.5 & 1.2 & 0.25 & 12.14 & 0.021 & 3.9 & 4.3 \\
\hline VTR5 Coubre St6 & 26.8 & 113 & 40 & & 1.6 & 1.4 & 0.27 & 12.21 & 0.022 & & 4.3 \\
\hline VTR5 Coubre St5 & 27.7 & 115 & 35 & & 1.6 & 1.4 & 0.25 & 12.20 & 0.021 & & 4.5 \\
\hline VTR5 Coubre St4 & 29.0 & 118 & 31 & & 1.7 & 1.2 & 0.23 & 11.93 & 0.019 & 4.6 & 4.5 \\
\hline VTR5 Coubre St2 & 29.9 & 129 & 21 & & 1.9 & 0.8 & 0.24 & 12.25 & 0.020 & 4.2 & 4.3 \\
\hline VTR5 Coubre St3 & 30.7 & 123 & 28 & & 1.7 & 1.4 & 0.22 & 13.00 & 0.017 & & 3.8 \\
\hline VTR5 Coubre St1 & 32.3 & 135 & 12 & & 6.3 & 2.3 & 0.21 & 8.40 & 0.025 & & 1.8 \\
\hline \multicolumn{12}{|c|}{ June 2009; discharge0729 $\mathrm{m}^{3} / \mathrm{s}$} \\
\hline VTR6 Coubre 10 & 24.6 & 94 & 15 & & 2.4 & 1.7 & 0.29 & 10.92 & 0.026 & 2.9 & 6.5 \\
\hline VTR6 Coubre 9 & 24.8 & 103 & 11 & & 3.2 & 1.9 & 0.33 & 11.69 & 0.028 & 4.0 & 8.0 \\
\hline VTR6 Coubre 8 & 26.7 & 108 & 9 & & & 2.0 & 0.29 & 11.46 & 0.025 & 2.6 & 6.5 \\
\hline VTR6 Coubre 7 & 27.9 & 112 & 5 & & 4.2 & 0.5 & 0.27 & 10.54 & 0.026 & 2.0 & 6.0 \\
\hline VTR6 Coubre 5 & 28.0 & 115 & 10 & & 3.1 & 1.4 & 0.30 & 12.17 & 0.025 & 3.7 & 6.1 \\
\hline VTR6 Coubre 6 & 29.4 & 114 & 9 & & 3.6 & 1.9 & 0.23 & 10.09 & 0.023 & 2.5 & 4.3 \\
\hline VTR6 Coubre 3 & 29.5 & 124 & 7 & & 6.8 & 1.7 & 0.23 & 9.33 & 0.024 & 2.4 & 3.4 \\
\hline
\end{tabular}


Table 1 (continued)

\begin{tabular}{lcccccccccccc}
\hline Station & $S$ & $\mathrm{PK}$ & $\begin{array}{l}\mathrm{SPM} \\
(\mathrm{mg} / \mathrm{L})\end{array}$ & $\begin{array}{l}\mathrm{DOC} \\
(\mathrm{mg} / \mathrm{L})\end{array}$ & $\begin{array}{l}\mathrm{POC} \\
(\%)\end{array}$ & $\begin{array}{l}\mathrm{Chl}-a \\
(\mu \mathrm{L} / \mathrm{L})\end{array}$ & $\begin{array}{l}\mathrm{Ag} \\
(\mathrm{mg} / \mathrm{kg})\end{array}$ & $\begin{array}{l}\mathrm{Th}_{\mathrm{P}} \\
(\mathrm{mg} / \mathrm{kg})\end{array}$ & $\begin{array}{c}\mathrm{Ag}_{\mathrm{P}} / \mathrm{Th}_{\mathrm{P}} \\
\mathrm{Ag}_{\mathrm{D}} \\
(\mathrm{ng} / \mathrm{L})\end{array}$ & $\begin{array}{l}\mathrm{UV}-\mathrm{Ag}_{\mathrm{D}} \\
(\mathrm{ng} / \mathrm{L})\end{array}$ \\
\hline VTR6 Coubre 4 & 30.1 & 120 & 7 & & 3.5 & 2.0 & 0.18 & 5.05 & 0.036 & 2.4 \\
VTR6 Coubre 1 & 31.1 & 133 & 9 & & 8.4 & 1.9 & 0.20 & 7.95 & 0.026 & 2.3 & 3.0 \\
VTR6 Coubre 2 & 31.1 & 129 & 7 & & 5.5 & 1.5 & 0.23 & 8.11 & 0.028 & 2.4 & 2.7 \\
WGMP & & & & & & & 0.26 & 9.6 & 0.027 & \\
\hline
\end{tabular}

Mean results ( $n 03$ ) for the West Gironde Mud Patch (WGMP) represent the pre-industrial period (1926-1940) for the Gironde watershed

freshwater SPM samples were collected twice monthly at Bordeaux (Fig. 1; Table 2) between March and October 2008. Sample location was defined by the distance from Bordeaux in kilometre, Bordeaux representing the kilometric point zero (KP0; Table 1). All SPM samples were dried at $50{ }^{\circ} \mathrm{C}$, then powdered and homogenised with an agate mortar and stored in sealed double PE bags in the dark.

Suspended particulate matter, particulate and dissolved organic carbon and chlorophyll- $a$ measurements

SPM concentrations in surface water were determined by filtration of precise water volumes through dry, pre-weighed filters (Whatman GF/F, $0.7 \mu \mathrm{m}$ ). The filters were then dried to constant weight at $45{ }^{\circ} \mathrm{C}$ and re-weighed.

Particulate organic carbon (POC) was measured directly from the dry, powdered and homogenised estuarine material using a carbon/sulphur analyser (LECO, CS-125). Prior to their combustion in an induction furnace, samples were acidified in crucibles with $2 \mathrm{M} \mathrm{HCl}$ to remove carbonates, then dried at $60^{\circ} \mathrm{C}$ to remove inorganic $\mathrm{C}$ and most of the remaining acid and water (e.g. Abril et al. 2002). The quality control included measurement of certified reference materials (e.g. LECO 501-503). Accuracy was within $5 \%$ of the certified values and the analytical error (RSD) generally better than $5 \%$. The analysis of dissolved organic carbon (DOC) in samples of filtered estuarine water (GFF filter, combusted at $450{ }^{\circ} \mathrm{C}$ during $5 \mathrm{~h}$ ) was performed by the high temperature catalytic oxidation method using a total organic carbon (TOC) analyser (Shimadzu, TOC 5000) as described elsewhere (Lemaire et al. 2006). Detection limits (3 sigma of the blank values) varied from 0.3 to $0.4 \mathrm{mg} / \mathrm{L}$ and reproducibility was generally better than $5 \%$ (RSD). Calibration was performed by dilution of a potassium phthalate solution. Details on the applied method and its analytical quality evaluated in an intercalibration between four European laboratories are given elsewhere (Abril et al. 2002).

Chlorophyll- $a$ (Chl- $a$ ) concentrations were measured during the 2009 cruises. Water was collected and immediately filtered through GFF Whatman filters $(25 \mathrm{~mm})$ and stored at $-80^{\circ} \mathrm{C}$ until their analysis by fluorometry (Trilogy,
Turner). Acetone (90 \%) was used as extraction solvent (Holm-Hansen et al. 1965). Dilutions of a Chl- $a$ standard solution (Anacystis nidulans, $1 \mathrm{mg} / \mathrm{L}$; C-6144; SigmaAldrich) were used to calibrate the fluorometer.

\section{Particulate silver $\left(\mathrm{Ag}_{\mathrm{P}}\right)$ analyses}

For total $\mathrm{Ag}_{\mathrm{P}}$ concentration analyses, SPM was homogenised and $30 \mathrm{mg}$ subsamples were digested in acid-washed PP tubes (DigiTUBEs ${ }^{\circledR}$, SCP Science) using $1.5 \mathrm{~mL} \mathrm{HCl}$ (12 M, Plasmapur, SCP Science), $0.75 \mathrm{~mL} \mathrm{HNO}_{3}(14 \mathrm{M}$, Plasmapur, SCP Science) and $2 \mathrm{~mL}$ HF (26 M, Plasmapur, SCP Science). The reactors were then heated at $110^{\circ} \mathrm{C}$ for $2 \mathrm{~h}$ in a heating block (DigiPREP MS ${ }^{\circ}$, SCP Science). After cooling, the digestates were evaporated to dryness. Each sample was brought to $10 \mathrm{~mL}$ using $150 \mu \mathrm{L} \mathrm{HNO}_{3}(14 \mathrm{M}$, Plasmapur) and Milli-Q water (Larrose et al. 2010).

The acid-soluble $\mathrm{Ag}_{\mathrm{HCl}}$ fraction, also called the reactive fraction (i.e. $1 \mathrm{M} \mathrm{HCl}$ extractible; e.g. Morse and Luther 1999), was extracted from freshwater SPM collected at Bordeaux (Table 2) by mixing subsamples $(200 \mathrm{mg}$ ) with $12.5 \mathrm{~mL}$ of $1 \mathrm{M} \mathrm{HCl}$ (Plasmapur, SCP Science) for $24 \mathrm{~h}$ using end-over-end tumbling at $12 \mathrm{rpm}$. After centrifugation $(3,000 \mathrm{rpm} ; 20 \mathrm{~min})$ the supernatant was retrieved and evaporated to dryness and the residues were brought to $10 \mathrm{~mL}$ as described for the tri-acid digestion procedure (see above). Single extractions by $1 \mathrm{M} \mathrm{HCl}$ were designed to extract trace metals bound to the reactive phases (e.g. Morse and Luther 1999) and have been proposed as a proxy to estimate the potentially bioavailable metal fractions, i.e. the fractions which may represent a threat to aquatic biota (Bryan and Langston 1992; Langston et al. 1999).

Both the solutions containing the total $\left(\mathrm{Ag}_{\mathrm{P}}\right)$ and the $\mathrm{HCl}$-extracted $\mathrm{Ag}_{\mathrm{HCl}}$ fractions were analysed by quadrupole ICP-MS (X7, Thermo-Fisher). As part of the quality control, the analytical accuracy was checked by parallel analyses of the international certified reference sediment NCS-DC70317 ( $n$ 06). The Ag recovery was evaluated at $112 \pm 5 \%$ and precision (RSD) was better than $4 \%$ at the $0.32 \mathrm{mg} / \mathrm{kg}$ level. Detection limits for total $\mathrm{Ag}_{\mathrm{P}}$ estimated as three times the standard deviation of method blanks obtained for the 
Table 2 Sampling date data for suspended particulate matter (SPM) collected at Bordeaux between March and October 2008, particulate Ag (Ag), particulate $\mathrm{Th}\left(\mathrm{Th}_{\mathrm{P}}\right), \mathrm{Ag}_{\mathrm{P}} / \mathrm{Th}_{\mathrm{P}}$, percentage of $\mathrm{Ag}_{\mathrm{P}}\left(\mathrm{Ag}_{\mathrm{HCl}}\right)$ and $\mathrm{Th}_{\mathrm{P}}\left(\mathrm{Th}_{\mathrm{HCl}}\right)$ extracted by $1 \mathrm{M} \mathrm{HCl}$ from SPM and resulting residual $\mathrm{Ag}\left(\mathrm{Ag}_{\mathrm{R}}\right)$

\begin{tabular}{|c|c|c|c|c|c|c|c|}
\hline Date & SPM (mg/L) & $\operatorname{Ag}_{P}(\mathrm{mg} / \mathrm{kg})$ & $\mathrm{Th}_{\mathrm{P}}(\mathrm{mg} / \mathrm{kg})$ & $\mathrm{AgP} / \mathrm{Th}_{\mathrm{P}}$ & $\mathrm{Ag}_{\mathrm{HCl}}(\%)$ & $\mathrm{Th}_{\mathrm{HCl}}(\%)$ & $\mathrm{Ag}_{\mathrm{R}}(\mathrm{mg} / \mathrm{kg})$ \\
\hline 03 March 2008 & 427 & 0.46 & 11.3 & 0.040 & 64 & 2 & 0.16 \\
\hline 17 March 2008 & 341 & 0.49 & 14.7 & 0.033 & 56 & 2 & 0.21 \\
\hline 01 April 2004 & 59 & 0.47 & 11.0 & 0.043 & 62 & 2 & 0.18 \\
\hline 14 April 2008 & 54 & 0.46 & 14.0 & 0.033 & 55 & 1 & 0.21 \\
\hline 28 April 2008 & 41 & 0.87 & 13.6 & 0.064 & 61 & 1 & 0.34 \\
\hline 13 May 2008 & 33 & 0.78 & 9.2 & 0.084 & 70 & 2 & 0.24 \\
\hline 02 June 2008 & 230 & 0.50 & 10.3 & 0.049 & 58 & 1 & 0.21 \\
\hline 16 June 2008 & 142 & 0.38 & 10.4 & 0.036 & 57 & 1 & 0.16 \\
\hline 03 July 2008 & 125 & 0.65 & 8.8 & 0.073 & 61 & 1 & 0.25 \\
\hline 21 July 2008 & 892 & 0.46 & 10.6 & 0.043 & 57 & 3 & 0.20 \\
\hline 31 July 2008 & 1,230 & 0.47 & 11.2 & 0.042 & 58 & 2 & 0.20 \\
\hline 28 August 2008 & 1,026 & 0.40 & 11.2 & 0.036 & 56 & 3 & 0.18 \\
\hline 18 September 2008 & 3,027 & 0.43 & 15.0 & 0.029 & 60 & 2 & 0.17 \\
\hline 29 September 2008 & 5,232 & 0.40 & 14.2 & 0.028 & 59 & 2 & 0.17 \\
\hline 16 October 2008 & 4,642 & 0.47 & 15.3 & 0.031 & 49 & 2 & 0.24 \\
\hline
\end{tabular}

total digestion procedure were $0.001 \mathrm{mg} / \mathrm{kg}(n$ 06). In order to remove the grain size effect (Larrose et al. 2010; Van Calsteren and Thomas 2006), the measured $\mathrm{Ag}_{\mathrm{P}}$ was normalised against particulate Th concentrations $\left(\mathrm{Th}_{\mathrm{P}}\right.$; Tables $\underline{1}$ and 2) obtained for the same samples.

\section{Dissolved silver $\left(\mathrm{Ag}_{\mathrm{D}}\right)$ analyses}

The dissolved Ag concentrations of filtered sample $\left(\mathrm{Ag}_{\mathrm{D}}\right)$ and $\mathrm{UV}$-irradiated replicates $\left(\mathrm{UV}-\mathrm{Ag}_{\mathrm{D}}\right.$ ) were measured by ICPMS after on-line solid-liquid ion exchange (preconcentration and matrix separation) using isotope dilution (Barriada et al. 2003; Ndung'u et al. 2006; Yang and Sturgeon 2002). Briefly, $12 \mathrm{~mL}$ samples were spiked $24 \mathrm{~h}$ before analysis with a known amount of ${ }^{107} \mathrm{Ag}$ in solution (Oak Ridge National Laboratory, TN, USA). After this equilibration time, the $12 \mathrm{~mL}$ samples passed through a minicolumn $(85 \mu \mathrm{L}$ internal volume; Global FIA, USA) filled with a strong anion-exchange resin (Dowex 1-X8, 200-400 mesh, Supelco) to retain the $\mathrm{Ag}_{\mathrm{D}}$ species (negatively charged $\mathrm{Ag}$ chlorocomplexes represent $85 \%$ of $\mathrm{Ag}_{\mathrm{D}}$ species present at only $50 \mathrm{mM}$ chloride concentration; Barriada et al. 2007). The saline matrix was rinsed off with Milli-Q water, followed by on-line elution $\left(\mathrm{HNO}_{3}, 2 \mathrm{M}\right.$, Plasmapur, SCP Science) to transport the preconcentrated $\mathrm{Ag}_{\mathrm{D}}$ species to the ICP-MS. The peak areas of the transient signals recorded were integrated with PlasmaLab software (Thermo Scientific). From the resulting modified isotope ratios, $\mathrm{Ag}_{\mathrm{D}}$ concentrations were calculated using the following equation (Rodriguez Martin-Doimeadios et al. 2003):

$C_{x}^{1 / 4 C_{y}} \times \frac{m_{y}}{m_{x}} \times \frac{A_{y}=B_{y} \times R_{n}}{B_{x} \times R_{n}-A_{x}} \times \frac{\mathrm{AW}_{\underline{x}}}{\mathrm{AW}_{y}}$ where $C_{x}$ is the analyte concentration (nanogram per millilitre); $C_{y}$ is the concentration of spike (nanogram per millilitre); $m_{y}$ is the volume of spike used to prepare the blend solution of sample and spike (millilitre); $m_{x}$ is the volume of the sample used (millilitre); $A_{y}$ is the abundance of the reference isotope in the spike; $B_{y}$ is the abundance of the spike isotope in the spike; $A_{x}$ is the abundance of the reference isotope in the sample; $B_{x}$ is the abundance of the spike isotope in the sample; $R_{n}$ is the measured reference/spike isotope ratio (mass bias-corrected) in the spiked sample; $\mathrm{AW}_{x}$ is the atomic weight of analyte in the sample and $\mathrm{AW}_{y}$ is the atomic weight of the spike.

Accuracy and precision were evaluated from parallel analyses of international certified reference freshwater (NIST-1640), estuarine water (SLEW-3) and nearshore seawater (CASS-4; Table 3 ). Only NIST-1640 is certified for $\mathrm{Ag}$ and SLEW-3 has an informational value of $3 \mathrm{ng} / \mathrm{L}$. However, values obtained for SLEW-3 and CASS-4 (with or without UV treatment) were comparable to Ag concentrations reported by Morford et al. (2008), Ndung'u et al. (2001, 2006) and Yang and Sturgeon (2002). Interestingly, dissolved Ag levels obtained for CASS-4 tended to be higher after UV treatment (Table $\underline{3}$ ), which is supported by the data from Ndung'u et al. (2006). Accuracy obtained for the analyses of NIST-1640 diluted 1,000-fold $(n 03)$ was $96 \pm$ $5 \%$ and precision (RSD) was better than $2 \%$ at the $0.8 \mathrm{ng} / \mathrm{L}$ level (Table 3 ). The detection limit (3 SD of $12 \mathrm{~mL}$ sample blanks) was $0.17 \mathrm{ng} / \mathrm{L}$ without $\mathrm{UV}$ treatment $(n 04)$ and $0.28 \mathrm{ng} / \mathrm{L}$ with UV treatment $(n 04)$. Comparison of data was done using the Spearman rank correlation coefficient $(R)$, a non-parametric method, considered significant when the $p$ value is inferior to $5 \%$. 
Table 3 Mean \pm standard deviation of dissolved $\mathrm{Ag}\left(\mathrm{Ag}_{\mathrm{D}}\right)$ concentrations in estuarine and nearshore seawater certified reference material (SLEW-3, CASS-4, CASS-5) and freshwater standard reference material (NIST-1640)

\begin{tabular}{|c|c|c|c|c|c|}
\hline Certified reference waters & Salinity & $\begin{array}{l}\text { Certified } \mathrm{Ag}_{\mathrm{D}} \\
\text { (ng/l) }\end{array}$ & $\begin{array}{l}\text { Measured } \mathrm{Ag}_{\mathrm{D}} \\
(\mathrm{ng} / \mathrm{l})\end{array}$ & $\begin{array}{l}\text { Number of individual } \\
\text { analyses }\end{array}$ & Reference \\
\hline \multicolumn{6}{|l|}{ Without UV treatment } \\
\hline NIST-1640 (diluted 1,000-fold) & 0 & 7.62 & $7.49 \pm 0.10$ & 3 & This study \\
\hline \multirow[t]{6}{*}{ CASS-4 } & \multirow[t]{6}{*}{30.7} & \multirow[t]{6}{*}{ nd } & $6.53 \pm 0.45$ & 3 & This study \\
\hline & & & $5.72 \pm 0.32$ & 5 & Morford et al. ( \\
\hline & & & $6.36 \pm 1.08$ & 2 & Morford et al. ( $\underline{2008})$ \\
\hline & & & $5.72 \pm 0.32$ & 15 & Morford et al. (2008) \\
\hline & & & $5.42 \pm 0.08$ & 3 & Yang and Sturgeon (2002) \\
\hline & & & $6.11 \pm 0.90$ & 7 & Ndung'u et al. (2001) \\
\hline CASS-5 & 33.5 & nd & $1.74 \pm 0.04$ & 5 & This study \\
\hline \multicolumn{6}{|l|}{ With UV treatment } \\
\hline NIST-1640 (diluted 1,000-fold) & 0 & 7.62 & $7.21 \pm 0.54$ & 3 & This study \\
\hline \multirow[t]{2}{*}{ SLEW-3 } & \multirow[t]{2}{*}{15} & \multirow[t]{2}{*}{$\sim 3$} & $2.64 \pm 0.39$ & 3 & This study \\
\hline & & & $2.97 \pm 0.77$ & 33 & Ndung'u et al. (2006) \\
\hline \multirow[t]{2}{*}{ CASS-4 } & \multirow[t]{2}{*}{30.7} & \multirow[t]{2}{*}{ nd } & $10.19 \pm 0.86$ & 3 & This study \\
\hline & & & $8.48 \pm 1.96$ & 21 & Ndung'u et al. (2006) \\
\hline
\end{tabular}

Daily $\mathrm{Ag}_{\mathrm{D}}$ net flux estimation

The commonly applied method for estimating dissolved metal net fluxes from estuaries to the coastal ocean (Boyle et al. 1974) is based on the dissolved element distribution in the estuarine high salinity range. According to Boyle et al. $(1974, \underline{1982})$, the instant net fluxes $\left(F_{t}\right)$ of a dissolved element $X$ across an isohaline $S$ at time $t$ is:

$F_{t}^{1 / 4} Q^{1 / 2 \mathrm{X}]-1 / 2 \Omega]} \frac{\left.\mathrm{d}^{\mathrm{d} / 2 \mathrm{X}]}\right]^{\Sigma}}{\mathrm{d}^{1} /[\mathrm{s}]}$

where $Q_{t}$ is the freshwater discharge at time $t,[X]$ is the concentration of the element of interest and $[S]$ is salinity. If the relation between the dissolved element concentration and the salinity is linear (conservative behaviour), $\mathrm{d}[X] / \mathrm{d}[S]$ is constant and equal to the slope of the segment representing this relation in the concentrationsalinity diagram. In this case, for any salinity $[S]$ belonging to the linearity range, $[X]_{S}-[S] \times\left(\mathrm{d}[X]_{S} / \mathrm{d}[S]\right)$ is constant and equal to the intercept $[X]^{0}$ of the straight line extrapo- lated from this segment. Accordingly, the net instanta- neous flux of the element through any isohaline in the linearity range is:

\section{$\left.F_{t}{ }^{1 / 4} Q_{t}{ }^{1} 1 / 2\right]^{0}$}

Using the average daily freshwater discharge $Q_{\text {fw }}$ provides an estimate of the daily net flux $\left(F_{\mathrm{NET}}\right)$ as follows:
$\left.F_{\mathrm{NET}} 1 / 4 Q_{\mathrm{fw}}{ }^{1 / 2 X}\right]^{0}$

The 'Port Autonome de Bordeaux' and the 'DIrection Régionale de l'ENvironement' provided the freshwater discharge data for the Garonne and the Dordogne Rivers, the two main tributaries of the Gironde Estuary (Fig. 1). Discharge data for the Gironde Estuary were estimated from the sum of the Garonne and the Dordogne River discharges added $15 \%$ to consider the commonly neglected contributions of minor tributaries to the Gironde Estuary, such as the Isle River and several small tributaries downstream of the discharge measurement stations (Schäfer et al. 2002).

\section{Results}

Hydrological conditions

The first cruise in April 2008 covered a flood event (mean freshwater discharge $2,320 \mathrm{~m}^{3} / \mathrm{s}$ ), causing a strong salinity front at the seaward end of the estuary with a 1-30 salinity gradient between KP60 and KP130 (Fig. 1). The March and June 2009 cruises took place in intermediate discharge conditions with mean freshwater flow rates of 747 and $729 \mathrm{~m}^{3 /}$ $\mathrm{s}$, respectively. June cruise focussed on $\mathrm{Ag}$ behaviour in the seaward end of the estuarine salinity gradient $(S>25)$, where SPM concentrations were generally low (Table 1 ). Annual freshwater fluxes to the Gironde Estuary for years 2008 $\left(30.5 \mathrm{~km}^{3}\right)$ and $2009\left(26.7 \mathrm{~km}^{3}\right)$ were typical of the $1990-$ 2007 period $\left(18-50 \mathrm{~km}^{3} /\right.$ year, mean $27 \pm 7 \mathrm{~km}^{3} /$ year; Dabrin et al. 2009; Schäfer et al. 2002). 
SPM, DOC, POC and Chl- $a$ along the estuarine salinity gradient

The SPM concentrations in surface water during the flood situation (April 2008) ranged from 12 to $2,660 \mathrm{mg} / \mathrm{L}$, i.e. showed values commonly observed in this turbid estuary (Dabrin et al. 2009), with a well-developed MTZ in the 1-7 salinity range (between KP70 and KP80; Table 1). During the moderate discharge situation in March 2009, the highest SPM concentrations of the MTZ were also located in the low salinity range $(0.1<S<0.7)$ but upstream from its position in the previous flood event of April 2008 (KP2 to KP55; Table 1). The SPM concentrations sampled were not greater than $256 \mathrm{mg} / \mathrm{L}$ but higher concentrations occurred between KP2 and KP22 that were not sampled. The SPM concentrations at Bordeaux ranged from 0.03 to $5.23 \mathrm{~g} / \mathrm{L}$ between March and October 2008 (Table 2). The highest concentrations $(>1 \mathrm{~g} / \mathrm{L})$ were reached in low discharge period (August to October) when the mean Gironde discharge was $223 \pm 54 \mathrm{~m}^{3} / \mathrm{s}$.

In April 2008, DOC ranged from 0.8 to $3.1 \mathrm{mg} / \mathrm{L}$ with the highest value coinciding with maximum SPM, i.e. in the low salinity range (Table 1 ). Level of POC in the Gironde Estuary (KP $<100 ; 1.5 \pm 0.2 \%$; Table 1 ) was equal to the value given by Etcheber et al. (2007). Higher POC level (up to $6.3 \%)$ occurred at the seaward end $(\mathrm{KP}>100)$ probably due to marine primary production.

During the low turbidity spring period (March 2009), Chl- $a$ concentrations ranged from 0.2 to $2.3 \mu \mathrm{g} / \mathrm{L}$ from salinity 0.1 to 32 (Table 1 ) and increased significantly with salinity $(R 00.60, p<0.05, n 020)$. Similar Chl $-a$ values $(0.5-2.0 \mu \mathrm{g} / \mathrm{L})$ occurred in the high salinity range (SO25-31) in June 2009, but were not related with salinity $(R 00.10, p>0.05, n 010)$. Such relatively low Chl- $a$ levels are typical for this turbid estuary and reflect the very limited light penetration and photochemical processes in the water column (Irigoien and Castel 1997).

Particulate silver distribution along the salinity gradient

Particulate $\mathrm{Ag}$ concentrations in Bordeaux freshwaters were 0.6 and $\sim 0.5 \mathrm{mg} / \mathrm{kg}$ in April 2008 and in March 2009, respectively (Fig. 2). These values are similar to typical $\mathrm{Ag}_{\mathrm{P}}$ concentrations measured in the Garonne River during the preceding decade (Lanceleur et al. 2011a). As salinity increased $\mathrm{Ag}_{\mathrm{P}}$ decreased progressively to $\sim 0.2 \mathrm{mg} / \mathrm{kg}$ in coastal seawater $(S>30)$, whatever the hydrological situation. A slightly different distribution was observed when $\mathrm{Ag}_{\mathrm{P}}$ concentrations were normalised by total particulate thorium ( $\mathrm{Th}_{\mathrm{P}}$; Table 1 ). In the freshwater zone, $\mathrm{Ag}_{\mathrm{P}} / \mathrm{Th}_{\mathrm{P}}$ ratios were relatively similar in April 2008 and March 2009 (0.049 and 0.041, respectively), i.e. independent from hydrological conditions. However, in the marine estuary $(S>25), \mathrm{Ag}_{\mathrm{P}} / \mathrm{Th}_{\mathrm{P}}$ was clearly lower during moderate discharge (means of 0.021 and 0.027 , respectively for March and June 2009; Table 1) than during the flood (0.039; April 2008), when $\mathrm{Ag}_{\mathrm{P}} / \mathrm{Th}_{\mathrm{P}}$ was close to typical freshwater values.

The SPM samples periodically recovered at Bordeaux tended to show two distinct $\mathrm{Ag}_{\mathrm{P}}$ levels, depending on SPM concentrations (Table 2). From March to July 2008 (SPM < $1 \mathrm{~g} / \mathrm{L} ; n 010)$, mean $\mathrm{Ag}_{\mathrm{P}}$ concentration was $0.55 \pm 0.16 \mathrm{mg} / \mathrm{kg}$ $\left(\mathrm{Ag}_{\mathrm{P}} / \mathrm{Th}_{\mathrm{P}} 00.050 \pm 0.018\right)$, of which $60 \pm 4 \%$ were extracted by $1 \mathrm{M} \mathrm{HCl}$. Accordingly, the $\mathrm{Ag}$ concentration in the residual fraction $\left(\mathrm{Ag}_{\mathrm{R}}\right.$; not extracted by $\left.1 \mathrm{M} \mathrm{HCl}\right)$ was $0.22 \pm 0.05 \mathrm{mg} /$ $\mathrm{kg}\left(\mathrm{Ag}_{\mathrm{R}} / \mathrm{Th}_{\mathrm{P}} 00.020 \pm 0.005\right)$. During the presence of the MTZ at Bordeaux (August to October 2008, SPM > $1 \mathrm{~g} / \mathrm{L}$; $n 05), \mathrm{Ag}_{\mathrm{P}}$ was $0.44 \pm 0.03 \mathrm{mg} / \mathrm{kg}\left(\mathrm{Ag}_{\mathrm{P}} / \mathrm{Th}_{\mathrm{P}} 00.033 \pm 0.006\right)$ with $56 \pm 5 \%$ extracted by $\mathrm{HCl}$, corresponding to a $\mathrm{Ag}_{\mathrm{R}}$ of $0.19 \pm 0.03 \mathrm{mg} / \mathrm{kg}\left(\mathrm{Ag}_{\mathrm{R}} / \mathrm{Th}_{\mathrm{P}} 00.015 \pm 0.003\right)$. In the sediments from the West Gironde Mud Patch ( $n 03$, data not shown; Fig. 1), $\operatorname{Ag}_{P}(0.26 \pm 0.02 \mathrm{mg} / \mathrm{kg})$ and $\operatorname{Ag}_{R}(0.23 \pm 0.02 \mathrm{mg} / \mathrm{kg})$ were similar with a common $\mathrm{Th}_{\mathrm{P}}$-normalised value $(0.027 \pm 0.001)$, i.e. nearly all $\mathrm{Ag}_{\mathrm{P}}$ was in the residual fraction.

Dissolved silver distribution in the salinity and turbidity gradients

The distribution of $\mathrm{Ag}_{\mathrm{D}}$ and $\mathrm{UV}-\mathrm{Ag}_{\mathrm{D}}$ along the salinity gradient followed a bell-shaped curve (Fig. $\underline{3}$ ), with UV$\mathrm{Ag}_{\mathrm{D}}$ from 0.7 to $8.0 \mathrm{ng} / \mathrm{L}$ and maximum values located in the 15-25 salinity range. Minimum concentrations for both $\mathrm{Ag}_{\mathrm{D}}$ and $\mathrm{UV}-\mathrm{Ag}_{\mathrm{D}}$ occurred either in the low salinity range $(0 \leq S \leq 3)$ where SPM concentrations were high, or in coastal seawater $(S \geq 30)$ at the estuary mouth. Values of UV$\mathrm{Ag}_{\mathrm{D}}$ recorded in Bordeaux freshwaters were $1.2 \mathrm{ng} / \mathrm{L}$ in March 2009 and $2.4 \mathrm{ng} / \mathrm{L}$ in April 2008, whereas the respective $\mathrm{UV}-\mathrm{Ag}_{\mathrm{D}}$ at the seaward end were 1.8 and $4.4 \mathrm{ng} / \mathrm{L}$ (i.e. 1.4- and 2-fold greater than freshwater values).

\section{Effect of UV treatment}

The $\mathrm{Ag}_{\mathrm{D}}$ fraction retained by the anionic chelating resin in the matrix separation step without previous UV treatment probably contains the anionic dissolved Ag complexes and 'labile' Ag metal-organic complexes. The UV irradiation prior to ion exchange chromatography aimed at breaking down (as far as possible) dissolved and colloidal (filter passing) Ag metalorganic complexes (Batley and Florence 1976), which are not retained by the anionic chelating resin without UV treatment. Accordingly, the UV-Ag $g_{D}$ fraction comprises both the $A g_{D}$ fraction and 'non-labile' Ag dissolved/colloidal metalorganic complexes, i.e. UV- $\mathrm{Ag}_{\mathrm{D}}$ may be considered as approaching the total dissolved $\mathrm{Ag}$ concentration. The difference between $\mathrm{UV}-\mathrm{Ag}_{\mathrm{D}}$ and $\mathrm{Ag} \mathrm{g}_{\mathrm{D}}$, attributed to 'non-labile' Ag dissolved/colloidal metal-organic complexes, 
Fig. 2 Particulate $\mathrm{Ag}$ concentrations $\left(\mathrm{Ag}_{\mathrm{P}}\right)$ and $\mathrm{Ag}_{\mathrm{P}} /$ $\mathrm{Th}_{\mathrm{P}}$ for the April 2008 (a), the March 2009 (a) and the June 2009 (c) cruises along the salinity gradient

\section{A April 2008}

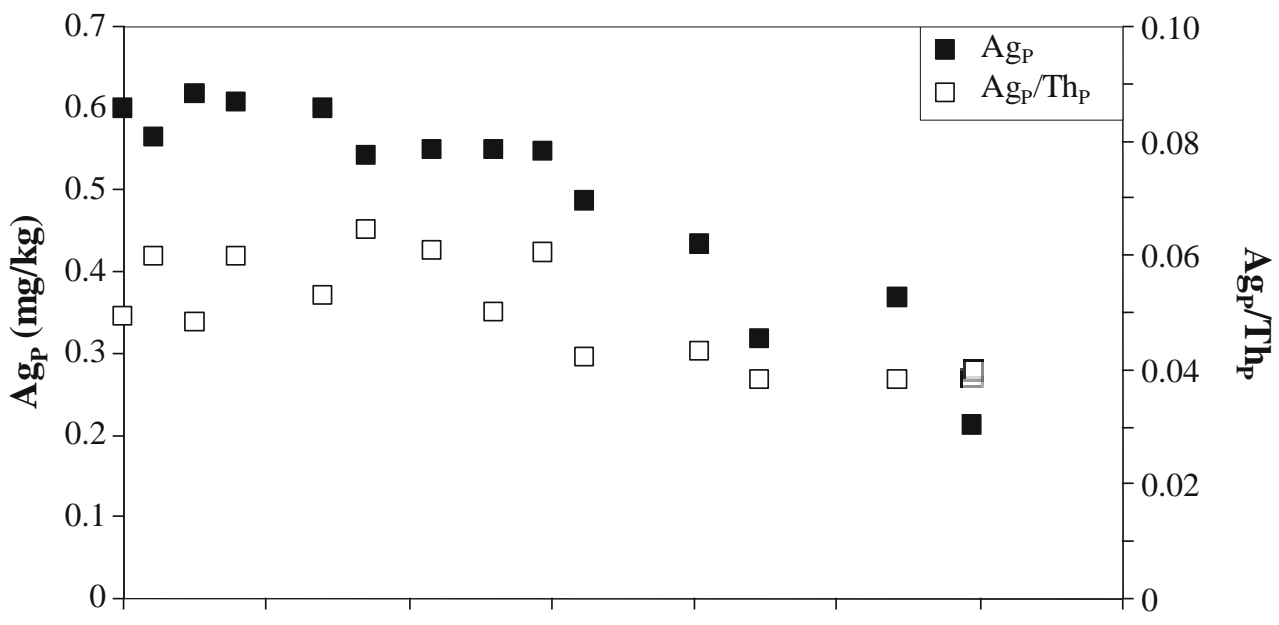

B March 2009

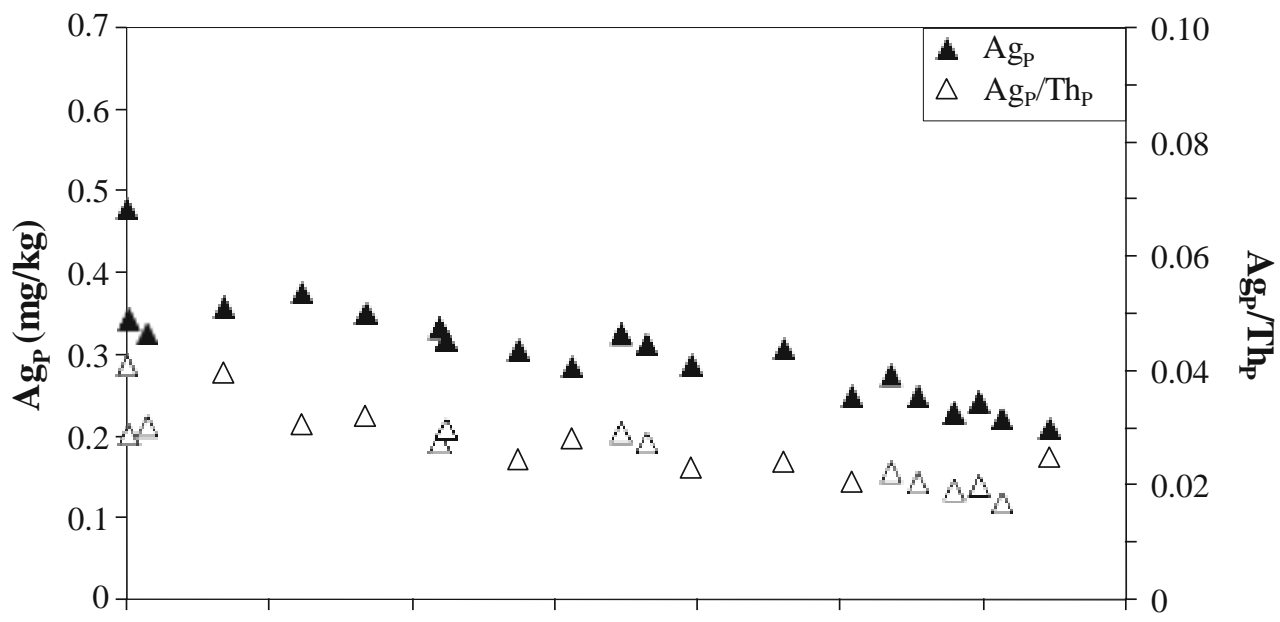

C June 2009

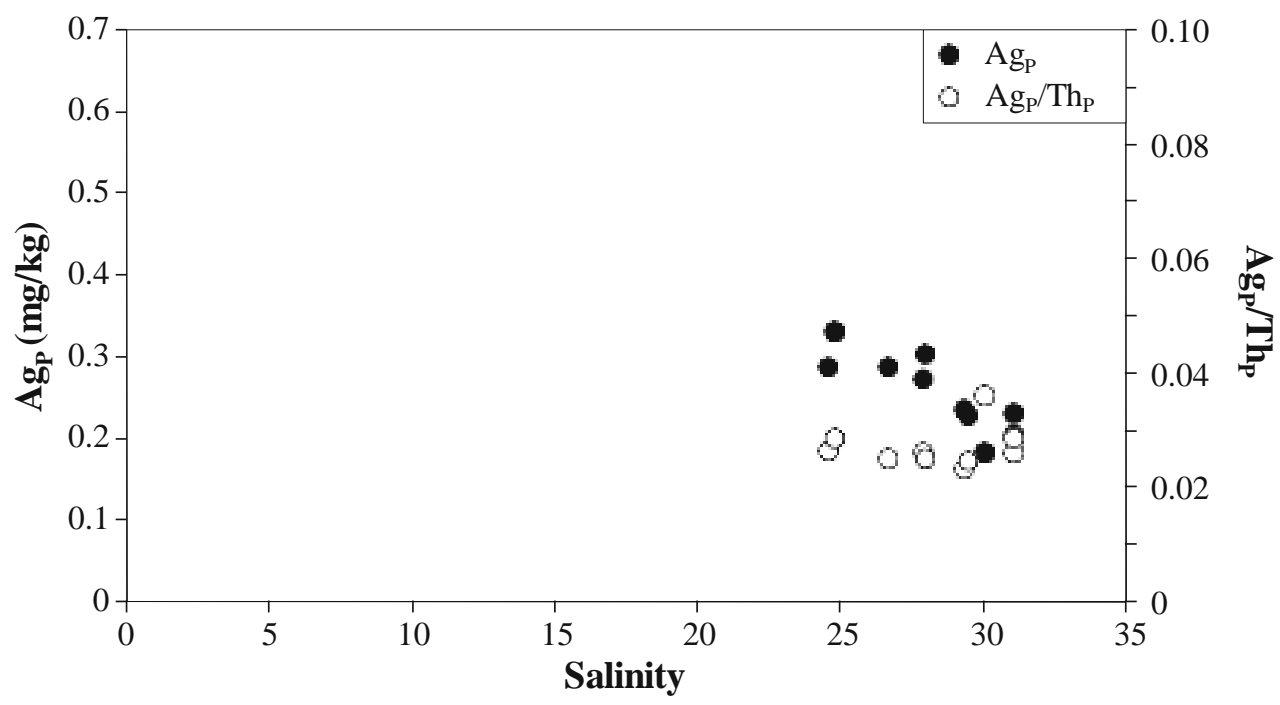


Fig. 3 Dissolved Ag

concentrations $\left(\mathrm{Ag}_{\mathrm{D}}\right.$ and $\mathrm{UV}$ $\left.\mathrm{Ag}_{\mathrm{D}}\right)$ and SPM for the April 2008 (a), the March 2009 (b) and the June 2009 (c) cruises along the salinity gradient. Black line: linear regression of used for net UV-Ag flux (Boyle et al. 1974, 1982) with correlation coefficient, $p$ value at the $95 \%$ confidence level, number of points used for each regression and equation of the dilution line. The white star represents North Atlantic Ocean $\mathrm{Ag}_{\mathrm{D}}$ (data from Rivera-Duarte et al. 1999$)$

\section{A April 2008}

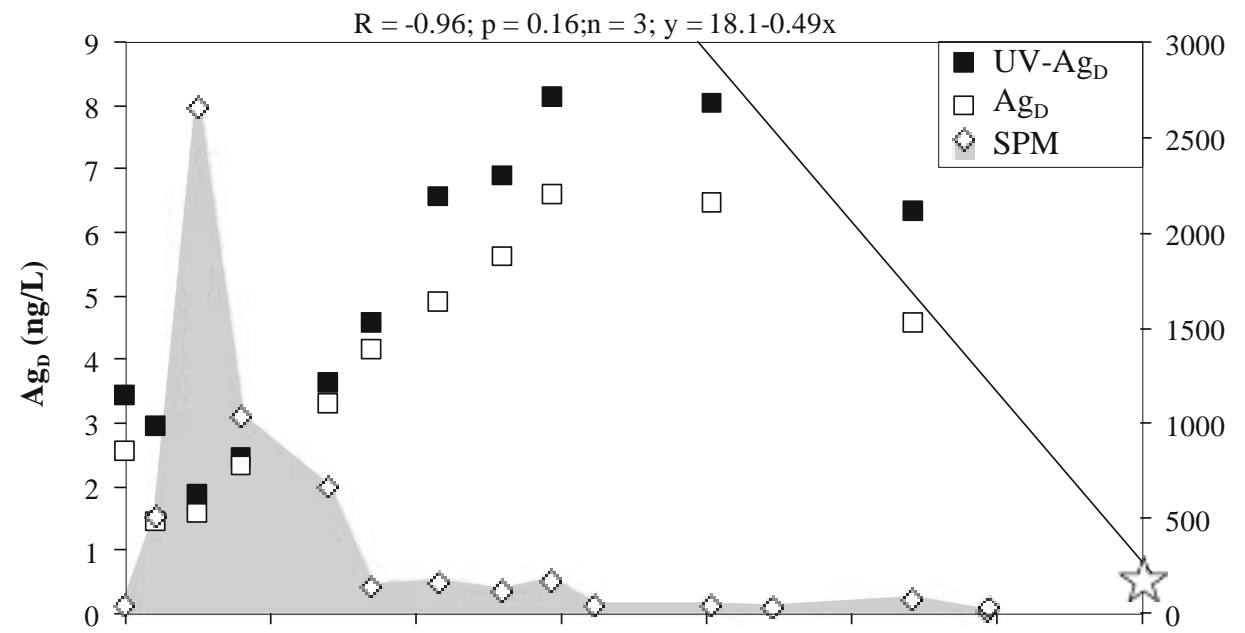

B March 2009

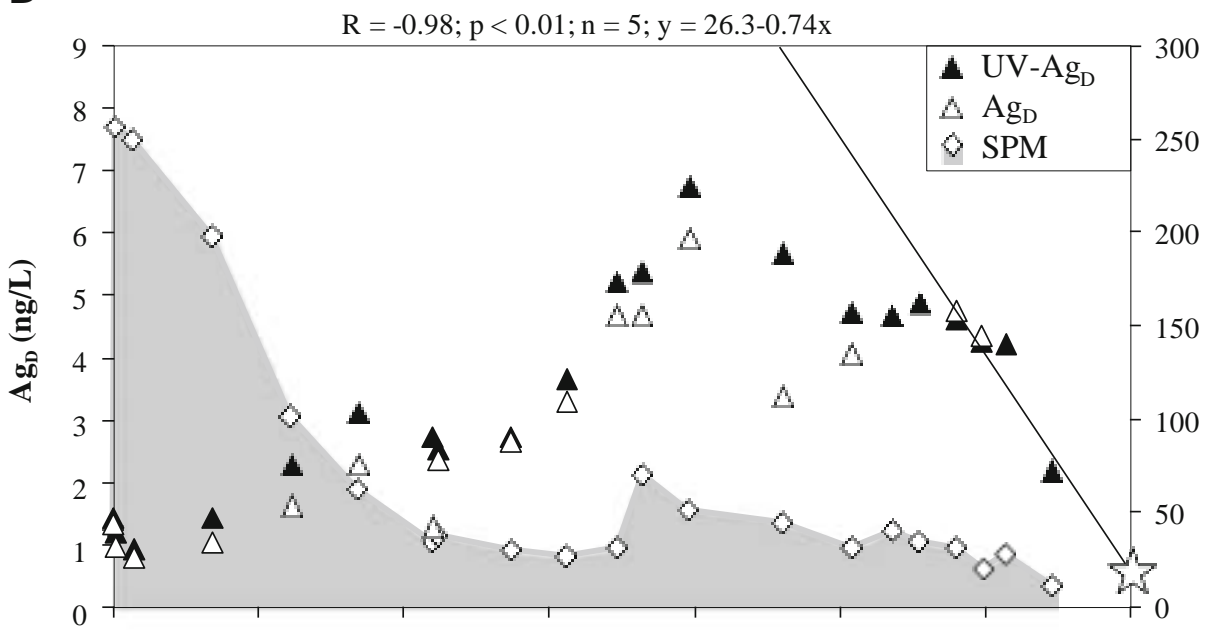

C June 2009

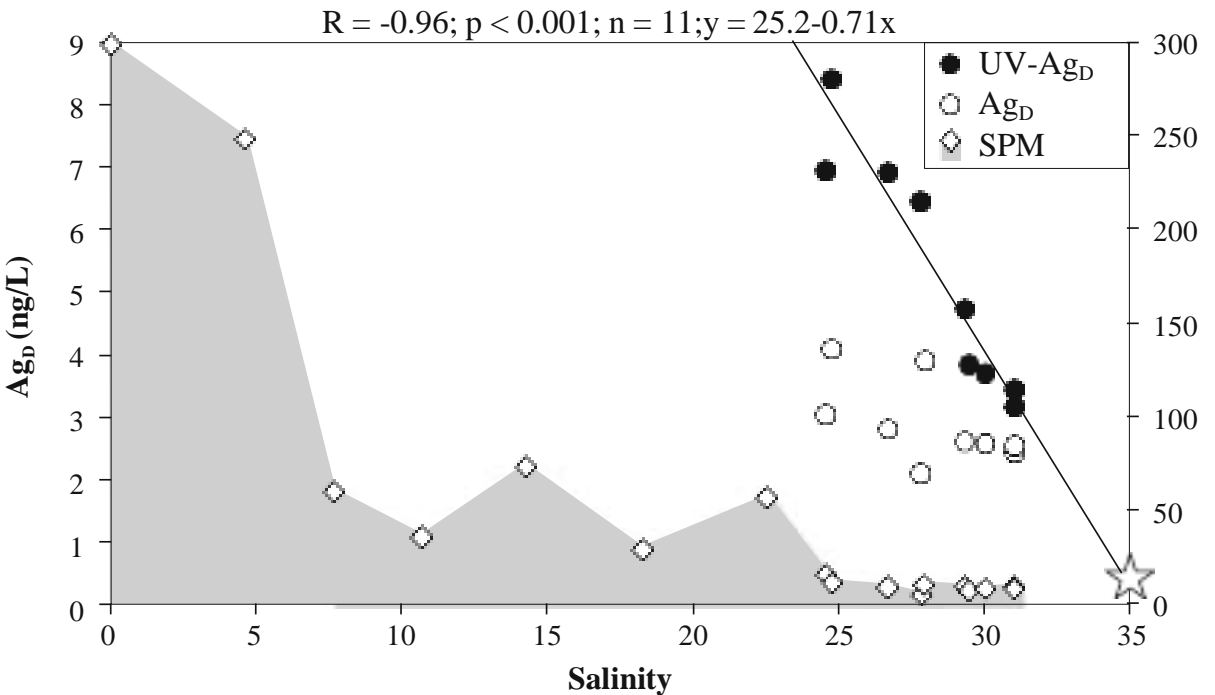

may provide valuable information on operationally defined dissolved Ag speciation (Batley and Florence 1976).
The results obtained from the three cruises showed that $\mathrm{UV}-\mathrm{Ag}_{\mathrm{D}}$ may be equal to or up to 3-fold greater than $\mathrm{Ag}$, 
depending on both salinity and SPM concentration (Fig. 3). For example, in April 2008, $\mathrm{Ag}_{\mathrm{D}}$ represented $100 \%$ of UV$\mathrm{Ag}_{\mathrm{D}}$ in the MTZ (SPM $02,660 \mathrm{mg} / \mathrm{L} ; S$ 02.5) and $75 \%$ upstream from the MTZ (SPM $075 \mathrm{mg} / \mathrm{L} ; S$ 027.1), i.e. the measured 'non-labile' Ag fraction accounted for $25 \%$ in the upstream estuary. The 2009 March and June data (Fig. 3b, c) also suggest that the non-labile fraction was high (up to 67 $\%$ of $\mathrm{UV}-\mathrm{Ag}_{\mathrm{D}}$ ) at $S>20$ and decreased to values ranged from close to 0 to $13 \%$ at higher salinities $(S>29)$, relatively independent from SPM concentrations.

\section{Discussion}

\section{Particulate silver behaviour in the estuary}

The major part $(96 \pm 2 \%)$ of $\mathrm{Ag}$ provided to the Gironde Estuary by its main tributary, i.e. the Garonne River, is associated to the particulate phase (Lanceleur et al. 2011a). It is therefore important to understand the fate of $\mathrm{Ag}_{\mathrm{P}}$ in the estuarine salinity and turbidity gradients.

The strong decrease in $\mathrm{Ag}_{\mathrm{P}}$ along the salinity gradient of the highly turbid Gironde Estuary is consistent with that reported for Japanese rivers flowing to Tokyo Bay $\left(\mathrm{Ag}_{\mathrm{P}}\right.$ decrease from 0.1 to $0.03 \mathrm{mg} / \mathrm{kg}$; i.e. $70 \%$; Zhang et al. 2008) and was attributed to desorption processes induced by chloride complexation (Ciffroy et al. 2003; Luoma et al. 1995). Comparing $\mathrm{Ag}_{\mathrm{P}}$ in SPM from the freshwater and the marine endmembers in April 2008 and March 2009 clearly suggests that 60 to $67 \%$ of $\mathrm{Ag}_{\mathrm{P}}$ was desorbed, i.e. added to the dissolved phase along the salinity gradient (Fig. 2a, b). This fraction mobilised is equivalent to $\mathrm{Ag}_{\mathrm{HCl}}$ in SPM from the freshwater estuary (60 $\pm 4 \%$; Bordeaux, March-July 2009, Table 2) upstream from the MTZ. Slightly lower $\mathrm{Ag}_{\mathrm{HCl}}$ fractions $(56 \pm 5 \%$; Bordeaux, August-October 2009) occurred in the presence of the MTZ, probably because MTZ particles are a mix of freshwater particles and older SPM from which $\mathrm{Ag}$ and other metals (e.g. $\mathrm{Cd}, \mathrm{Cu}$ ) have previously been partly mobilised (Masson et al. 2006). The $\mathrm{Ag}_{\mathrm{HCl}}$ fractions in freshwater SPM from the Gironde Estuary are greater than, but consistent with, those of oxidised surface sediment from 17 English estuaries (25-40\%; Luoma and Bryan 1981). This may be due to (a) differences in SPM origin/composition and/or (b) previous partial $\mathrm{Ag}$ desorption induced by chlorides. The latter hypothesis was supported by experimental study showing that $55-85 \%$ of the particle-bound $\mathrm{Ag}$ in estuarine sediments previously exposed to a $80 \mu \mathrm{g} / \mathrm{L} \mathrm{Ag}$ solution during 14 days was extractable by $\mathrm{HCl}(0.5 \mathrm{M}$; Luoma et al. 1995).

In a previous work, Lanceleur et al. (2011a) have established the grain size corrected geochemical background of $\mathrm{Ag}$ in SPM from the Gironde Estuary watershed as $\mathrm{Ag}_{\mathrm{P}} / \mathrm{Th}_{\mathrm{P}} 0$ 0.026. Sediments constituting the West Gironde Mud
Patch, localised near the North Channel of the Gironde Estuary (Fig. 1), are mainly derived from estuarine SPM (Schmidt et al. 2005). In fact, $\mathrm{Ag}_{\mathrm{P}} / \mathrm{Th}_{\mathrm{P}}$ values $\left(\mathrm{Ag}_{\mathrm{P}} / \mathrm{Th}_{\mathrm{P}} 0\right.$ $0.027 ; n 03)$ in these sediments representing the 1926-1940 period $(40 \mathrm{~cm}$ depth), i.e. before the increase of metalworking industry in the Lot River basin (Audry et al. 2004; Schmidt et al. 2005), are similar to those observed in SPM from the high salinity range during intermediate freshwater discharge ( 0.027; March and June 2009). Conversely, the $\mathrm{Ag}_{\mathrm{P}} / \mathrm{Th}_{\mathrm{P}}$ value (0.040) in SPM from the high salinity range $(S>20)$ was clearly greater during high discharge and higher tidal currents (tidal coefficient065) in April 2008 as a result of lower $\mathrm{Th}_{\mathrm{P}}$ values (Table 1 ). These results suggest (a) that $\mathrm{Ag}$ desorption from SPM is highly efficient during intermediate discharge and results in residual $\mathrm{Ag}_{\mathrm{P}} / \mathrm{Th}_{\mathrm{P}}$ levels similar or lower than the geochemical background and (b) that during the flood event, SPM from the estuary mouth were coarser, probably due to an increasing fraction of fine sand, the dominant sediment in the estuary mouth (Larrose et al. 2010), and still contained potentially desorbable $\mathrm{Ag}_{\mathrm{P}}$.

Based on the geochemical background, Lanceleur et al. (2011a) attributed $\mathrm{Ag}_{\mathrm{P}} / \mathrm{Th}_{\mathrm{P}}$ ratios higher than 0.026 to the adsorption of $\mathrm{Ag}_{\mathrm{D}}$ released by anthropogenic activities on $\mathrm{SPM}$. Consequently, the anthropogenic $\mathrm{Ag}_{\mathrm{P}}$ fraction belongs to the operationally defined reactive $\mathrm{Ag}_{\mathrm{P}}$ fraction (i.e. $1 \mathrm{M} \mathrm{HCl}$ extractible). Because $\mathrm{Th}$ is highly insoluble in seawater (Van Calsteren and Thomas 2006), this means that (a) the estuarine salinity mobilises at least the equivalent of whole anthropogenic component of $\mathrm{Ag}_{\mathrm{P}}$ (similar to $1 \mathrm{M}$ $\mathrm{HCl})$ and (b) this anthropogenic fraction is potentially bioavailable. Assuming that the $\mathrm{Ag}$ desorbed in the salinity gradient is bioavailable, particulate $\mathrm{Ag}$ transport to the estuary and subsequent desorption is probably the major $\mathrm{Ag}$ source accounting for the anomalously high Ag concentrations in estuarine oysters (up to $110 \mathrm{mg} / \mathrm{kg}$, dry weight; Lanceleur et al. 2011b). During the flood, Ag desorption inside the estuary is incomplete, probably due to the relatively short particle residence times ( 1 week), and expulsion of estuarine particles to the coastal ocean is at maximum (Castaing and Allen 1981). In these conditions, Ag release from particles probably occurs in the coastal seawater and may affect the nearby Marennes Oléron Bay, where oyster cultures are exposed to particles derived from the Gironde Estuary (Strady et al. 2011).

\section{Dissolved Ag distribution}

In river water, $\mathrm{Ag}_{\mathrm{D}}$ rapidly sorbs onto particles (Davis $\underline{1977}$; Smith and Flegal 1993), but this process is reversible, as $\mathrm{Ag}_{\mathrm{P}}$ also is rapidly desorbed (e.g. by $0.5 \mathrm{M} \mathrm{HCl}$; Luoma et al. 1995). In the brackish part of the Gironde Estuary, the $\mathrm{Ag}_{\mathrm{D}}$ profiles are typical for metals undergoing chlorocomplexation (e.g. Cd, Dabrin et al. 2009), i.e. they show a mid- 
salinity maximum in the dissolved phase, reflecting the balance between induced complexation processes and dilution by seawater (e.g. Comans and van Dijk 1988). Accordingly, the observed increase in $\mathrm{Ag}_{\mathrm{D}}$ concentrations with salinity (Fig. 3) was attributed to chloride-induced desorption, which is consistent with the results from other estuaries (Luoma et al. 1995; Tappin et al. 2010; Wen et al. 1997).

Although very high SPM concentrations (e.g. $2.8 \mathrm{~g} / \mathrm{L}$ in April 2008) probably imply very high amounts of potentially desorbable $\mathrm{Ag}$ in the MTZ, no addition of $\mathrm{Ag}_{\mathrm{D}}$ was observed in the respective salinity range $(0<S<3$; Fig. 3 ). This suggests that in highly turbid conditions, adsorption on SPM prevails over chloride-induced desorption at low salinity. Our results obtained for the Ag partitioning in the Gironde Estuary are in good agreement with previous experiments showing that $>99 \%$ of $\mathrm{Ag}$ from a $100 \mathrm{~mL}$ solution $(80 \mu \mathrm{g} / \mathrm{L})$ was adsorbed by $2 \mathrm{~g}$ of oxidised estuarine sediment in $24 \mathrm{~h}$ at salinity 20 (Luoma et al. 1995).

The seaward part of the bell-shaped curve (Fig. $\underline{3}$ ) reflects dilution of Ag-rich estuarine waters by seawater $\left(\mathrm{Ag}_{\mathrm{D}} \mathrm{O}\right.$ $0.39 \mathrm{ng} / \mathrm{L}$, station 4, North Atlantic Ocean; Rivera-Duarte et al. 1999). This seaward-dipping $\mathrm{Ag}_{\mathrm{D}}$ gradient follows the gradient of $\mathrm{Ag}$ bioaccumulation in oysters at three stations within the Gironde Estuary mouth (La Fosse site, $15<S<$ 20; Fig. 1) towards the outer station (Bonne Anse, $S>25$; Chiffoleau et al. 2005; Lanceleur et al. 2011b). The $\mathrm{Ag}_{\mathrm{D}}$ values in the Gironde Estuary were similar in magnitude to those reported for the Fal Estuary (southwest England; 9.8土 $6.7 \mathrm{ng} / \mathrm{L}$; Tappin et al. 2010) receiving acid mine drainage from numerous disused mine workings over a protracted period, the inner part of the Fal Estuary, i.e. Restronguet Creek, being considered as the most metal-polluted estuary in the UK (Tappin et al. 2010). However, the $\mathrm{Ag}_{\mathrm{D}}$ distributions along the salinity gradients were different between the highly turbid Gironde Estuary (SPM 5-2,660 $\mathrm{mg} / \mathrm{L}$ ) and the weakly turbid Fal Estuary (SPM 2-9 mg/L), where $\mathrm{Ag}_{\mathrm{D}}$ increased from $3.5 \mathrm{ng} / \mathrm{L}$ in freshwater to a maximum of $19.5 \mathrm{ng} / \mathrm{L}$ as soon as salinity reaches 6 . This suggests that $\mathrm{Ag}_{\mathrm{D}}$ levels and distribution in estuarine salinity gradients strongly depend on the balance between desorption and adsorption, i.e. SPM levels and distribution.

Wen et al. (1997) showed that Ag was partially associated with colloidal macromolecular organic matter in the Trinity River Estuary (15-70 \% of $\mathrm{Ag}_{\mathrm{D}}$ species in $<0.45 \mu \mathrm{m}$ filtered water were greater than $1 \mathrm{kDa}$, decreasing with increasing salinity). In the Gironde Estuary, maximum DOC levels typically occur in the MTZ (Table 1) reflecting (a) accelerated particulate organic matter decomposition due to oxic and anoxic oscillations in the MTZ and (b) accumulation of DOC in the fluid mud periodically resuspended by tidal currents and/or dredging (Abril et al. 1999). However, despite high DOC levels, $\mathrm{Ag}_{\mathrm{D}}$ and $\mathrm{UV}-\mathrm{Ag}_{\mathrm{D}}$ were similar in nearly all samples from the well-developed MTZ for SPM >
$200 \mathrm{mg} / \mathrm{L}$ (April 2008; Fig. 3a), suggesting the absence of non-labile filter-passing colloidal metal-organic Ag complexes in the MTZ. In contrast, at low SPM levels, the nonlabile fractions accounted for up to $25 \%$ of $\mathrm{Ag}_{\mathrm{D}}$ and were not correlated with DOC in April 2008. Further speci- ation investigations combining different cut-offs and sepa- ration techniques (e.g. Lemaire et al. 2006) are needed to better understand the behaviour of dissolved/colloidal Ag species in the Gironde Estuary.

\section{Dissolved silver net fluxes}

As water and particles in the Gironde Estuary have very different residence times (respectively 20-90 days and $\sim 1-$ 2 years; Jouanneau and Latouche 1981), there is no simple relation between $\mathrm{Ag}_{\mathrm{D}}$ and $\mathrm{Ag}_{\mathrm{P}}$ concentrations and fluxes. However, taking the average $\mathrm{Ag}_{\mathrm{P}}$ concentration $(0.55 \pm$ $0.16 \mathrm{mg} / \mathrm{kg}$ ) in SPM from Bordeaux sampled in freshwater and at low turbidity (Table 2 ), a potential desorption equal to $60 \%$ of $\mathrm{Ag}_{\mathrm{P}}$ and the average SPM gross flux to the estuary during the past decade (1.5 $10^{6} \mathrm{t}$ /year), the annual $\mathrm{Ag}_{\mathrm{D}}$ net flux was roughly estimated at $0.35-0.64$ t/year. This estimate is consistent with that obtained from Boyle's method (Boyle et al. 1974, 1982) applied to our dataset. For this, a marine endmember $\left(\mathrm{Ag}_{\mathrm{D}} 00.39 \mathrm{ng} / \mathrm{L}\right.$; measured at $56^{\circ} \mathrm{N}$ 25.5 $\mathrm{W}$; Rivera-Duarte et al. 1999) was plotted on our $\mathrm{Ag}_{\mathrm{D}}$ profiles (Fig. 3 ), and the theoretic $\mathrm{Ag}_{\mathrm{D}}$ concentrations were estimated at zero salinity $\left(\mathrm{Ag}_{\mathrm{D}}{ }^{0}\right)$ using the $\mathrm{UV}-\mathrm{Ag}_{\mathrm{D}}$ data.

The $\mathrm{Ag}_{\mathrm{D}}{ }^{0}$ values obtained for intermediate freshwater discharge conditions were $26 \pm 8 \mathrm{ng} / \mathrm{L}$ in March $2009(n 0$ 5; $R 0-0.98 ; p<0.01$ ) and $25 \pm 4 \mathrm{ng} / \mathrm{L}$ in June 2009 ( $n$ 011; $r 0-0.97 ; p<0.001)$, stated at the $95 \%$ confidence level. The dataset obtained for the flood (April 2008) did not allow a confidence interval estimation but the linear decrease in $\mathrm{Ag}_{\mathrm{D}}$ in the high salinity range suggested $\mathrm{Ag}_{\mathrm{D}}{ }^{0}$ was $\sim 25 \mathrm{ng} / \mathrm{L}$, i.e. similar to the other profiles. This observation is consistent with previous work on cadmium $(\mathrm{Cd})$ net fluxes in the Gironde Estuary, showing that the theoretical dissolved $\mathrm{Cd}$ concentration at zero salinity $\left(\mathrm{Cd}_{\mathrm{D}}{ }^{0}\right)$ did not vary much during intermediate and high discharge (Dabrin et al. 2009). The daily $\mathrm{Ag}_{\mathrm{D}}$ net flux was estimated at $5.01 \mathrm{~g} /$ day during the flood (April 2008) and $1.68 \pm 0.52 \mathrm{~g} /$ day (March 2009) and 1.57 $\pm 0.25 \mathrm{~g}$ /day (June 2009) for intermediate freshwater discharges. Applying an $\mathrm{Ag}_{\mathrm{D}}{ }^{0}$ of $25 \pm 4$ $\mathrm{ng} / \mathrm{L}$ (June 2009) to the annual freshwater flux in the Gironde Estuary, we estimated annual $\mathrm{Ag}_{\mathrm{D}}$ net fluxes (i.e. ejected off the Gironde Estuary) at 0.64-0.89 t/year in 2008 and $0.56-0.77 \mathrm{t} /$ year in 2009.

The estuarine Ag mass balance (i.e. input vs output) was improved by accounting the particle and water residence times in the estuary (1-2 years and 20-90 days, respectively). Accordingly, we combined the estimated $\mathrm{Ag}_{\mathrm{P}}$ gross fluxes during 2006-2008 (data from Lanceleur et al. 
2011a), the 2008/2009 $\mathrm{Ag}_{\mathrm{D}}$ gross fluxes via the Garonne and Dordogne Rivers (Lanceleur et al. 2011a; Garonne River: La Réole site; Dordogne River, $40 \%$ and $27 \%$ contribution to $A g_{D}$ and $A g_{P}$ gross fluxes to the Gironde Estuary, respectively) and the $A g_{P}$ desorption potential of $60 \%$ (this study). The resulting potential (estimated from river input) $\mathrm{Ag}_{\mathrm{D}}$ net flux of 0.45-0.74 t/year for 2008/2009 was very close to our $\mathrm{Ag}_{\mathrm{D}}$ net flux obtained from Boyle's method (estimated at the Gironde Estuary highest salinities), i.e. the contribution of intra-estuarine $\mathrm{Ag}$ sources (e.g. sorption/desorption of $\mathrm{Ag}$ with bed sediments and benthic fluxes of $\mathrm{Ag}_{\mathrm{D}}$; Rivera-Duarte and Flegal 1997) appeared small $(<20 \%)$.

However, this mass balance does not take into account potential Ag desorption in the coastal ocean from particles exported before being depleted in desorbable $\mathrm{Ag}_{\mathrm{P}}$ (e.g. during floods), which may partially mask the contribution of intra estuarine Ag sources. In fact, historical records of Ag bioaccumulation in oysters from the estuary mouth (Lanceleur et al. $\underline{2011 b}$ ) clearly suggest a growing influence of $\mathrm{Ag}$ from recent sources such as urban wastewater and cloud seeding. Because these potential sources are (at least partly) intra-estuarine (e.g. the Bordeaux agglomeration and vineyards on the Gironde Estuary banks), further work must aim at quantifying their part in the estuarine $\mathrm{Ag}$ budget and pollution.

\section{Conclusion}

In the salinity gradient of the Gironde Estuary, $\mathrm{Ag}_{\mathrm{P}}$ in riverborne SPM decreased by 60-67 \% due to chloride-induced desorption. This fraction is similar to the potentially bioavailable, short-term reactive fraction as assessed by selective extraction $\left(\mathrm{Ag}_{\mathrm{HCl}}\right)$, suggesting that the SPM average residence time in the estuary (1-2 years) allows complete desorption of the reactive $\mathrm{Ag}$ fraction. Silver-depleted SPM from the estuary mouth showed $\mathrm{Ag}_{\mathrm{P}} / \mathrm{Th}_{\mathrm{P}} 0$ 0.019-0.028 during intermediate discharge, which is similar or lower than values in sediment from the West Gironde Mud Patch $\left(\mathrm{Ag}_{\mathrm{P}} / \mathrm{Th}_{\mathrm{P}} \mathrm{O} 0.027 \pm 0.001\right)$ and the geochemical background of the Gironde watershed $\left(\mathrm{Ag}_{\mathrm{P}} / \mathrm{Th}_{\mathrm{P}} 0\right.$ 0.0240.028; Lanceleur et al. 2011a). Higher values $\left(\mathrm{Ag}_{\mathrm{P}} / \mathrm{Th}_{\mathrm{P}} \mathrm{O}\right.$ 0.040) during a flood suggest that exportation of nondepleted particles may result in $\mathrm{Ag}$ desorption in the coastal ocean and in the adjacent oyster farming areas in the Marennes-Oléron Bay. The Ag partitioning in the estuary reflects the balance between adsorption and desorption, i.e. by both salinity and SPM concentration, with minimum $A g_{D}$ in the MTZ and maximum levels (6-9 times greater than minimum $A g_{D}$ ) in the mid-salinity range. Filter-passing $(<0.2 \mu \mathrm{m})$ non-labile metal-organic Ag complexes assessed by solid-liquid extraction with and without previous UV treatment were not detectable in the MTZ and were highly variable in the $\mathrm{mid} / \mathrm{high}$ salinity range (SO20-33) where they accounted for up to $67 \%$ (typically 10 to $50 \%$; average $28 \%$ ) of total dissolved $\mathrm{Ag}\left(\mathrm{UV}-\mathrm{Ag}_{\mathrm{D}}\right)$.

Different approaches provided the first estimates of $\mathrm{Ag}_{\mathrm{D}}$ net fluxes during the three cruises (flood $5.0 \mathrm{~g} /$ day; intermediate discharge $\sim 1.7 \mathrm{~g} /$ day) and at the annual time scale (0.64-0.89 t/year in 2008 and $0.56-0.77 \mathrm{t} /$ year in 2009). The first tentative Ag budget for the whole Gironde Estuary clearly showed that further work is necessary to understand the contribution of probable intra-estuarine $\mathrm{Ag}$ sources (e.g. Bordeaux urban agglomeration and agricultural activities).

Acknowledgments We thank S. Schmidt and J. Troncinsky for providing dated sediment samples from the West Gironde Mud Patch. We gratefully acknowledge the captains and crews of the RV 'Côtes de la Manche' (INSU) and S. Castelle, A. Dabrin, H. Derriennic and M. Masson for their help during field work. This work was supported by the CYTRIX EC2CO VOTR'TRAM Project and the ANR «Vulnérabilité, Milieu et Climat» (ANR-07-VULN-003).

\section{References}

Abril G, Etcheber H, Le Hir P, Bassoullet P, Boutier B, Frankignoulle $M$ (1999) Oxic/anoxic oscillations and organic carbon mineralization in an estuarine maximum turbidity zone (The Gironde, France). Limnol Oceanogr 44:1304-1315

Abril G, Nogueira M, Etcheber H, Cabeçadas G, Lemaire E, Brogueira MJ (2002) Behaviour of organic carbon in nine contrasting European estuaries. Estuar Coast Shelf Sci 54:241-262

Audry S, Blanc G, Schäfer J, Chaillou G, Robert S (2006) Early diagenesis of trace metals $(\mathrm{Cd}, \mathrm{Cu}, \mathrm{Co}, \mathrm{Ni}, \mathrm{U}, \mathrm{Mo}$, and $\mathrm{V})$ in the freshwater reaches of a macrotidal estuary. Geochim Cosmochim Acta 70:2264-2282

Audry S, Schäfer J, Blanc G, Bossy C, Lavaux G (2004) Anthropogenic components of heavy metal $(\mathrm{Cd}, \mathrm{Zn}, \mathrm{Cu}, \mathrm{Pb})$ budgets in the Lot-Garonne fluvial system (France). Appl Geochem 19:769-786

Ayrault S, Rianti Priadi C, Evrard O, Lefèvre I, Bonté P (2010) Silver and thallium historical trends in the Seine River basin. J Environ Monit 12:2177-2185

Barriada JL, Tappin AD, Evans HE, Achterberg EP (2007) Dissolved silver measurements in seawater. Trends Anal Chem 26:809-817

Barriada JL, Truscott JB, Achterberg EP (2003) Automation of a flow injection system for the determination of dissolved silver at picomolar concentrations in seawater with inductively coupled plasma mass spectrometry. J Autom Method Manag 25:93-100

Batley GE, Florence TM (1976) Determination of the chemical forms of dissolved cadmium, lead and copper in seawater. Mar Chem 4:347-363

Boyle EA, Collier R, Dengler AT, Edmond JM, Ng AC, Stallard RF (1974) On the chemical mass-balance in estuaries. Geochim Cosmochim Acta 38:1719-1728

Boyle EA, Huested SS, Grant B (1982) The chemical mass balance of the Amazon plume-II. Copper, nickel and cadmium. Deep-Sea Res 29:1355-1364

Bryan GW, Langston WJ (1992) Bioavailability, accumulation and effects of heavy metals in sediments with special reference to United Kingdom estuaries: a review. Environ Pollut 76:89-131

Castaing P, Allen GP (1981) Mechanisms controlling seaward escape of suspended sediment from the Gironde: a macrotidal estuary in France. Mar Geol 40:101-118 
Castelle S, Schäfer J, Blanc G, Audry S, Etcheber H, Lissalde J-P (2007) 50-year record and solid state speciation of mercury in natural and contaminated reservoir sediment. Appl Geochem 22:1359-1370

Chiffoleau J-F, Auger D, Roux N, Rozuel E, Santini A (2005) Distribution of silver in mussels and oysters along the French coasts: data from the national monitoring program. Mar Pollut Bull 50:1719-1723

Ciffroy P, Garnier J-M, Benyahya L (2003) Kinetic partitioning of Co, $\mathrm{Mn}, \mathrm{Cs}, \mathrm{Fe}, \mathrm{Ag}, \mathrm{Zn}$ and $\mathrm{Cd}$ in fresh waters (Loire) mixed with brackish waters (Loire estuary): experimental and modelling approaches. Mar Pollut Bull 46:626-641

Comans RNJ, van Dijk CPJ (1988) Role of complexation processes in cadmium mobilization during estuarine mixing. Nature 336:151154

Coynel A, Schäfer J, Blanc G, Bossy C (2007) Scenario of particulate trace metal and metalloid transport during a major flood event inferred from transient geochemical signals. Appl Geochem 22:821-836

Dabrin A, Schäfer J, Blanc G, Strady E, Masson M, Bossy C, Castelle S, Girardot N, Coynel A (2009) Improving estuarine net flux estimates for dissolved cadmium export at the annual timescale: application to the Gironde Estuary. Estuar Coast Shelf Sci 84:429-439

Davis JA (1977) Adsorption of trace metals and complexing ligands at the oxide/water interface. PhD thesis, Stanford University, Stanford, California, pp. 176

Eisler R (1996) Silver hazards to fish, wildlife, and invertebrates: a synoptic review. Biol Sci Rep 32:44

Engel DW, Sunda WG, Fowler BA (1981) Factors affecting trace metal uptake and toxicity to estuarine organisms. I. Environmental parameters. In: Vernberg F, Calabrese A, Thurberg FP, Vernberg WB (eds) Biological monitoring of marine pollutants. Academic, New York, pp 127-144

Etcheber H, Taillez A, Abril G, Garnier J, Servais P, Moatar F, Commarieu MV (2007) Particulate organic carbon in the estuarine turbidity maxima of the Gironde, Loire and Seine estuaries: origin and lability. Hydrobiologia 588:245-259

Flegal AR, Brown CL, Squire S, Ross JRM, Scelfo GM, Hibdon S (2007) Spatial and temporal variations in silver contamination and toxicity in San Francisco Bay. Environ Res 105:34-52

Gobeil C, Rondeau B, Beaudin L (2005) Contribution of municipal effluents to metal fluxes in the St. Lawrence River. Environ Sci Technol 39:456-464

Holm-Hansen O, Lorenzen CJ, Holmes RW, Strickland JDH (1965) Fluorometric determination of chlorophyll. J Cons Int Explor Mer 30:3-15

Hornberger MI, Luoma SN, Cain DJ, Parchaso F, Brown CL, Bouse RM, Wellise C, Thompson JK (2000) Linkage of bioaccumulation and biological effects to changes in pollutant loads in South San Francisco Bay. Environ Sci Technol 34:2401-2409

Irigoien X, Castel J (1997) Light limitation and distribution of chlorophyll pigments in a highly turbid estuary: the Gironde estuary (SW France). Estuar Coast Shelf Sci 44:507-517

Jouanneau JM, Latouche C (1981) The Gironde Estuary. In: Fürchtbauer H, Lisitzyn AP, Millerman JD, Seibold E (eds) Contribution to sedimentology. E. Schweizerbart'sche Verlagsbuch-handlung, Stuttgart, pp 1-115

Lanceleur L, Schäfer J, Bossy C, Coynel A, Larrose A, Masson M, Blanc G (2011a) Silver fluxes to the Gironde Estuary-11 years (1999-2009) of monitoring at the watershed scale. Appl Geochem 26:797-808

Lanceleur L, Schäfer J, Chiffoleau J-F, Blanc G, Auger D, Renault S, Baudrimont M, Audry S (2011b) Long-term records of cadmium and silver contamination in sediments and oysters from the
Gironde fluvial-estuarine continuum-evidence of changing silver sources. Chemosphere 85:1299-1305

Langston WJ, Burt GR, Pope ND (1999) Bioavailability of metals in sediments of the Dogger Bank (central North Sea): a mesocosm study. Estuar Coast Shelf Sci 48:519-540

Larrose A, Coynel A, Schäfer J, Blanc G, Masse L, Maneux E (2010) Assessing the current state of the Gironde Estuary by mapping priority contaminant distribution and risk potential in surface sediment. Appl Geochem 25:1912-1923

Lemaire E, Blanc G, Schäfer J, Coynel A (2006) Dissolved trace metalorganic complexes in the Lot-Garonne River system determined by the C18 Sep-pak system. Aquat Geochem 12:21-38

Luoma SN, Bryan GW (1981) A statistical assessment of the form of trace metals in oxidized surface sediments employing chemical extractants. Sci Total Environ 17:165-196

Luoma SN, Ho YB, Bryan GW (1995) Fate, bioavailability and toxicity of Ag in estuarine environments. Mar Pollut Bull 31:44-54

Masson M, Blanc G, Schäfer J (2006) Geochemical signals and source contributions to heavy metal $(\mathrm{Cd}, \mathrm{Zn}, \mathrm{Pb}, \mathrm{Cu})$ fluxes into the Gironde Estuary via its major tributaries. Sci Total Environ 370:133-146

Morford JL, Kalnejais LH, Helman P, Yen G, Reinard M (2008) Geochemical cycling of silver in marine sediments along an offshore transect. Mar Chem 110:77-88

Morse JW, Luther GW III (1999) Chemical influences on trace metalsulfide interactions in anoxic sediments. Geochim Cosmochim Acta 63:3373-3378

Ndung'u K, Thomas MA, Flegal AR (2001) Silver in the western equatorial and South Atlantic Ocean. Deep-Sea Res II 48:29332945

Ndung'u K, Ranville MA, Franks RP, Flegal AR (2006) On-line determination of silver in natural waters by inductively-coupled plasma mass spectrometry: influence of organic matter. Mar Chem 98:109-120

Ratte HT (1999) Bioaccumulation and toxicity of silver compounds: a review. Environ Toxicol Chem 18:89-108

Rivera-Duarte I, Flegal AR (1997) Pore-water silver concentration gradients and benthic fluxes from contaminated sediments of San Francisco Bay, California, U.S.A. Mar Chem 56:15-26

Rivera-Duarte I, Flegal AR, Sañudo-Wilhelmy SA, Veron AJ (1999) Silver in the far North Atlantic Ocean. Deep-Sea Res II 46:979-990

Rodriguez Martin-Doimeadios RC, Monperrus M, Krupp E, Amouroux D, Donard OFX (2003) Using speciated isotope dilution with GC-inductively coupled plasma MS to determine and unravel the artificial formation of monomethylmercury in certified reference sediments. Anal Chem 75:3202-3211

Rozan TF, Hunter KS (2001) Effects of discharge on silver loading and transport in the Quinnipiac River, Connecticut. Sci Total Environ 279:195-205

Sañudo-Wilhelmy SA, Flegal AR (1992) Anthropogenic silver in the southern California Bight: a new tracer of sewage in coastal waters. Environ Sci Technol 26:2147-2151

Schäfer J, Blanc G (2002) Relationship between ore deposits in river catchments and geochemistry of suspended particulate matter from six rivers in southwest France. Sci Total Environ 298:103118

Schäfer J, Blanc G, Lapaquellerie Y, Maillet N, Maneux E, Etcheber H (2002) Ten-year observation of the Gironde tributary fluvial system: fluxes of suspended matter, particulate organic carbon and cadmium. Mar Chem 79:229-242

Schmidt S, Tronczynski J, Guiot N, Lefevre I (2005) Dating of sediments in the Biscay bay: implication for pollution chronology. Radioprotection 40:655-660

Smith GJ, Flegal AR (1993) Silver in San Francisco Bay estuarine waters. Estuar Coasts 16:547-558 
Sottolichio A, Castaing P (1999) A synthesis on seasonal dynamics of highly concentrated structures in the Gironde Estuary. C R Acad Sci II A 329:795-800

Strady E, Blanc G, Baudrimont M, Schäfer J, Robert S, Lafon V (2011) Roles of regional hydrodynamic and trophic contamination in cadmium bioaccumulation by pacific oysters in the MarennesOléron Bay (France). Chemosphere 84:80-90

Tappin AD, Barriada JL, Braungardt CB, Evans EH, Patey MD, Achterberg EP (2010) Dissolved silver in European estuarine and coastal waters. Water Res 44:4204-4216

U.S. EPA (Environmental Protection Agency) (2002) National recommended water quality criteria: 2002. EPA 882-R-02047. Washington, DC: U. S. E.P.A., pp. 33. Available at: http://www.epa.gov/waterscience/criteria/wqcriteria.html
Van Calsteren P, Thomas L (2006) Uranium-series dating applications in natural environmental science. Earth Sci Rev 75:155-175

Wen L-S, Santschi PH, Gill GA, Paternostro CL, Lehman RD (1997) Colloidal and particulate silver in river and estuarine water of Texas. Environ Sci Technol 31:723-731

Wu F, Cai Y, Evans D, Dillon P (2004) Complexation between $\mathrm{Hg}$ (II) and dissolved organic matter in stream waters: an application of fluorescence spectroscopy. Biogeochemistry 71:339-351

Yang L, Sturgeon RE (2002) On-line determination of silver in seawater and marine sediment by inductively coupled plasma mass spectrometry. J Anal At Spectrom 17:88-93

Zhang Y, Obata H, Gamo T (2008) Silver in Tokyo Bay estuarine waters and Japanese rivers. J Oceanogr 64:259-265 